\title{
Alkaline Phosphatase and Hypophosphatasia
}

\author{
José Luis Millán ${ }^{1}$ Michael P. Whyte ${ }^{2,3}$
}

Received: 16 September 2015/Accepted: 28 October 2015/Published online: 21 November 2015

(C) The Author(s) 2015. This article is published with open access at Springerlink.com

\begin{abstract}
Hypophosphatasia (HPP) results from ALPL mutations leading to deficient activity of the tissue-nonspecific alkaline phosphatase isozyme (TNAP) and thereby extracellular accumulation of inorganic pyrophosphate $\left(\mathrm{PP}_{\mathrm{i}}\right)$, a natural substrate of TNAP and potent inhibitor of mineralization. Thus, HPP features rickets or osteomalacia and hypomineralization of teeth. Enzyme replacement using mineral-targeted TNAP from birth prevented severe HPP in TNAP-knockout mice and was then shown to rescue and substantially treat infants and young children with life-threatening HPP. Clinical trials are revealing aspects of HPP pathophysiology not yet fully understood, such as craniosynostosis and muscle weakness when HPP is severe. New treatment approaches are under development to improve patient care.
\end{abstract}

Keywords Rickets - Osteomalacia - Enzyme replacement $\cdot$ Calcification $\cdot$ Seizures

José Luis Millán

millan@burnham.org

1 Sanford Children's Health Research Center, Sanford Burnham Prebys Medical Discovery Institute, La Jolla, CA 92037, USA

2 Center for Metabolic Bone Disease and Molecular Research, Shriners Hospital for Children, St. Louis, MO 63110, USA

3 Division of Bone and Mineral Diseases, Washington University School of Medicine at Barnes-Jewish Hospital, St. Louis, MO 63110, USA

\section{Introduction}

In 1923, Robert Robison, Ph.D. discovered a phosphatase abundant in the skeleton possibly to generate inorganic phosphate $\left(\mathrm{P}_{\mathrm{i}}\right)$ required to form bone mineral [1]. In 1932, he postulated that an additional but unknown factor regulates skeletal mineralization [2]. This factor would prove to be inorganic pyrophosphate $\left(\mathrm{PP}_{\mathrm{i}}\right)$, a potent inhibitor of mineralization and natural substrate for Robison's enzyme [3]. The phosphatase, now called tissue-non-specific alkaline phosphatase (TNAP, or TNSALP), is encoded by the ALPL gene [4] expressed richly in bone, liver, and kidney, but also in the central nervous system, fibroblasts, and endothelial and other cell types. Hypomorphic ALPL mutation(s) cause hypophosphatasia (HPP) [4], a rare form of rickets or osteomalacia [5] featuring low serum alkaline phosphatase (ALP) activity and with an incidence for its most severe forms of 1:100,000 [6] and 1:300,000 [7] in the general population [6] of North America and Europe, respectively, but 1 per 2500 births in Canadian Mennonites [8]. The efficacy of enzyme replacement therapy (EzRT) using a mineral-targeted form of recombinant TNAP has been demonstrated for severe HPP [9]. Our review summarizes knowledge concerning TNAP, including revelations about its physiological function coming from investigation of HPP patients and mouse models and successes using EzRT.

\section{The Enzyme}

In humans, three genes besides $A L P L$ ( $A L P I, A L P P$, and $A L P P L 2)$ encode alkaline phosphatase (ALP) isozymes, but with restricted tissue expression; i.e., "intestinal," "placental," and "germ cell" ALP and are not compromised in HPP [10]. TNAP structure modeling is based on its sequence 


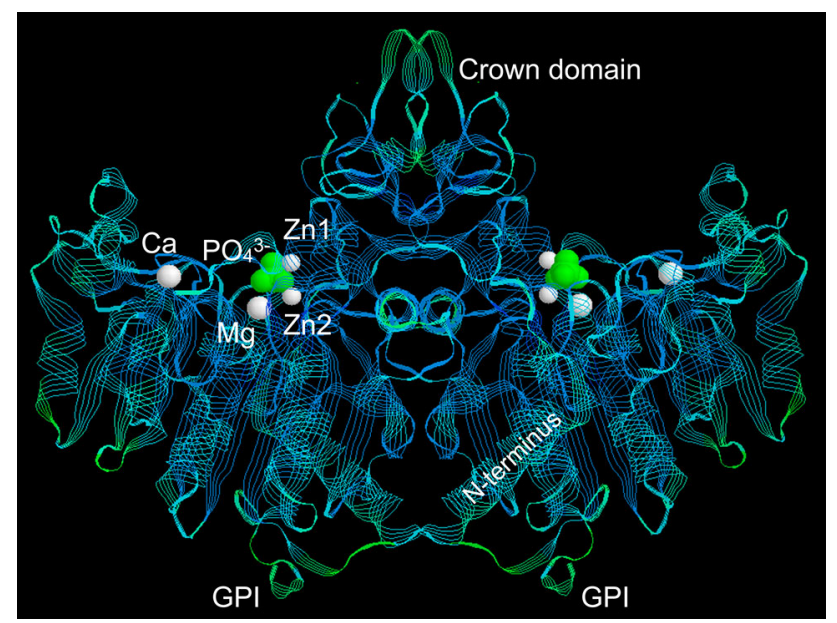

Fig. 1 Ribbon representation of the 3D structure of alkaline phosphatase (1EW2) [10]. The active site phosphate $\left(\mathrm{PO}_{4}{ }^{3-}\right)$ bound to Ser92 during catalysis is shown in green. The three active site metal ions, two $\mathrm{Zn}^{2+}(\mathrm{Zn} 1$ and $\mathrm{Zn} 2)$ and one $\mathrm{Mg}^{2+}(\mathrm{Mg})$, are shown in white as well as the structural $\mathrm{Ca}^{2+}$ ion $(\mathrm{Ca})$. Also indicated are the flexible exposed sequence known as the "crown domain"; the $\mathrm{N}$-terminal helix of one subunit that reaches close to the active site of the contralateral subunit; and the location where the glycosylphosphatidylinositol (GPI) anchor is attached to the C-terminus of the mature enzyme (Color figure online)

homology to the placental isozyme (PLAP) for which crystallographic coordinates have been determined [11]. TNAP functions physiologically as a homodimer (Fig. 1) [12]. The two monomers become related by a twofold crystallographic axis, with the monomer-monomer interface displaying a strong hydrophobic character with fewer than $30 \%$ of its amino acid residues (hereafter "residues") involved in hydrogen-bonding interactions [13]. This feature renders the monomer-monomer interface crucial for stability and enzymatic function, and TNAP (and mammalian ALPs in general) is therefore an obligatory homodimer. A flexible surface loop, "the crown domain," contains residues important for stabilizing the binding of uncompetitive TNAP inhibitors, such as E429 and Y367 [14-16]. Furthermore, this domain contains a low-affinity collagen-binding motif [16]. The N-terminal $\alpha$-helix (residues 9-25) of each monomeric subunit reaches the active site of the contralateral subunit (Fig. 1) [17]. Both the crown domain and the $\mathrm{N}$-terminal arm help stabilize the dimeric structure and determine allosteric properties [18]. Thus, structural and functional properties explain how some hypomorphic $A L P L$ alleles compromise the kinetic properties of the entire dimer (a dominant-negative effect) leading to TNAP insufficiency and generation-to-generation inheritance of HPP [19]. Three metal-binding sites surrounding the catalytic Ser residue are essential for TNAP enzymatic activity; i.e., M1 and M2 (occupied by $\mathrm{Zn}^{2+}$ ) and $\mathrm{M} 3$ (occupied by $\mathrm{Mg}^{2+}$ ) $[11,14]$. An additional metal-binding site, M4, apparently occupied by $\mathrm{Ca}^{2+}$ and absent in bacterial ALPs, was revealed by solving the 3D structure of PLAP $[11,20]$. However, this M4 structural metal site does not influence TNAP catalytic activity [21]. During TNAP-mediated catalysis, $\mathrm{Zn}^{2+}$ ions occupy the $\mathrm{M} 1$ and $\mathrm{M} 2$ sites, $\mathrm{Mg}^{2+}$ the $\mathrm{M} 3$ site, and $\mathrm{Ca}^{2+}$ the M4 site. With skeletal mineralization, the increasing $\mathrm{Ca}^{2+}$ gradient in the extracellular matrix first activates TNAP by replacing the $\mathrm{Mg}^{2+}$ with $\mathrm{Ca}^{2+}$ at $\mathrm{M} 3$, but at high $\mathrm{Ca}^{2+}$ concentrations, it gradually deactivates TNAP as $\mathrm{Ca}^{2+}$ competes out the $\mathrm{Zn}^{2+}$ from the M1 and M2 metal sites [21]. This explains why TNAP loses activity at the completion of the mineralization process [22].

Thus, ALPL mutations that alter residues at the monomer-monomer interface, the crown domain, the $\mathrm{N}$-terminal arm, and the divalent cation-binding sites can all cause HPP [20]. Additionally, post-translational modifications of TNAP are important. TNAP (indeed all mammalian ALPs) is bound to the surface of plasma membranes via a glycosylphosphatidylinositol (GPI) anchor that enables movement of the enzyme by enhancing membrane fluidity [23]. This GPI anchor can be cleaved by the enzymatic action of phospholipases found in plasma membranes, perhaps explaining how TNAP is released into the circulation and other biological fluids [24]. Also, TNAP contains five putative N-linked glycosylation sites, N123, N213, N254, N286, and N413 [25], with the sugar chains required for catalytic activity [26]. The types of sugars in TNAP explain the different biophysical and kinetic properties of its "isoforms" produced by bone, liver, kidney, and vascular cells [27].

In vitro, TNAP has broad substrate specificity and can hydrolyze or transphosphorylate a considerable variety of compounds [10]. However, only a few [inorganic pyrophosphate $\left(\mathrm{PP}_{\mathrm{i}}\right)$, pyridoxal 5'-phosphate (PLP), and likely phosphoethanolamine (PEA)] are natural substrates for TNAP based on studies of HPP patients and fibroblasts and Alpl knockout (KO) mice [28, 29]. Nevertheless, it is unclear what metabolic pathway leads to PEA accumulation [27, 29]. Recent studies also suggest that ATP [30-32], di-phosphoryl lipopolysaccharide (LPS) [33], and phosphorylated osteopontin (p-OPN) [34] are natural substrates of TNAP.

\section{The Disease}

HPP features extraordinarily broad-ranging severity (Fig. 2), but all patients carry one or two loss-of-function mutations in their $A L P L$ alleles $[4,35,36]$. Traditionally, HPP is classified in the clinic firstly by whether there are dental manifestations alone (i.e., without skeletal disease or other complications), and then according to the patient's age when any additional complications initially manifested. Thus, in order of decreasing severity, clinicians 

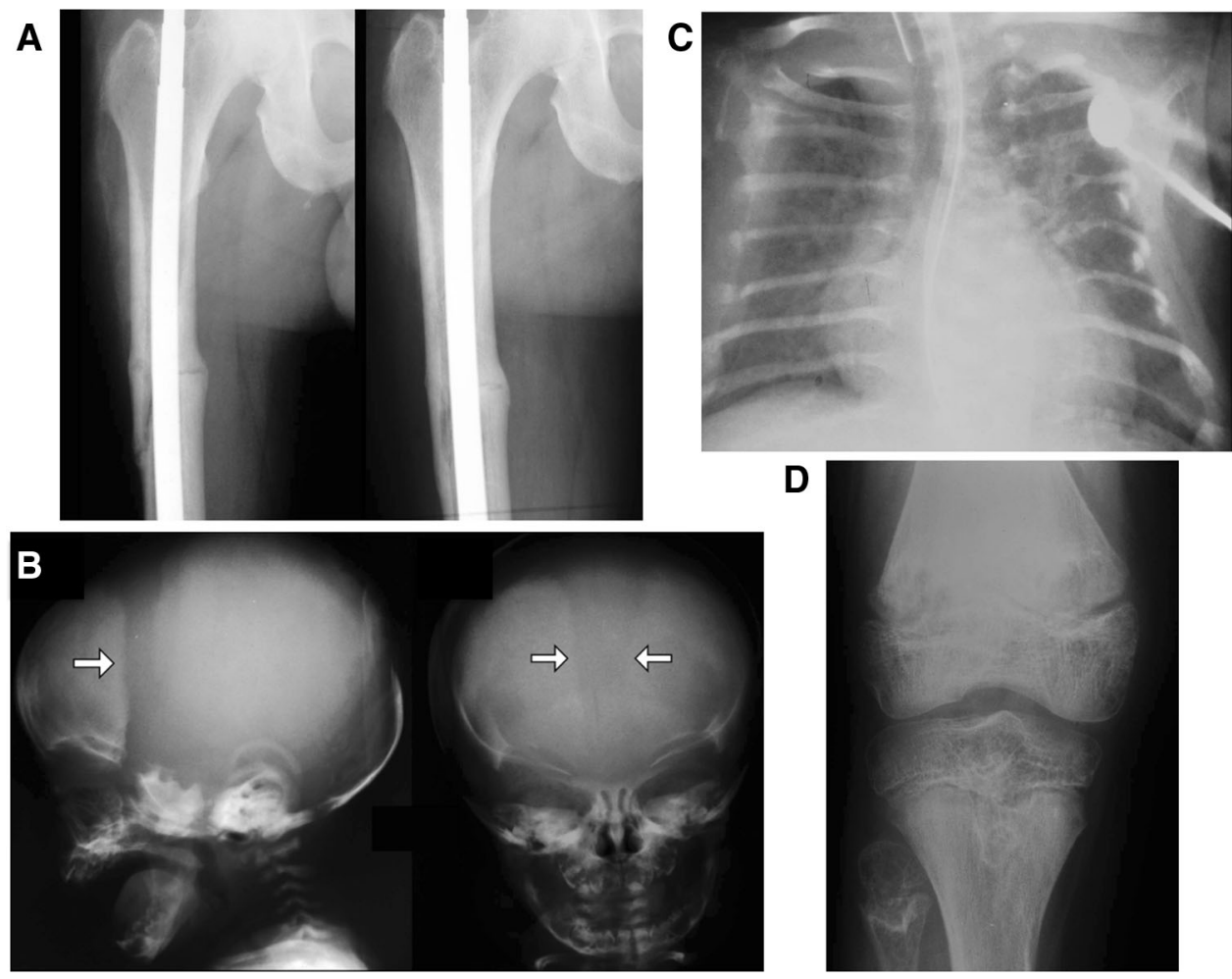

Fig. 2 Radiographic images of HPP patients. a This middle-aged man who manifested signs and symptoms of hypophosphatasia during childhood shows some healing of a right femoral pseudofracture treated with intramedullary fixation. b Lateral and anteroposterior radiograph of the skull of this 14-week-old baby with infantile hypophosphatasia shows characteristic hypomineralization of areas of the calvarium that give the appearance of widened sutures (arrows). c At 23 weeks-of-age, this radiograph of the chest of a baby with

recognize perinatal HPP, infantile HPP, childhood HPP, adult HPP, and odonto-HPP [35]. Perinatal HPP is detectable in utero using fetal sonography, and can cause stillbirth or be fatal soon after [37]. Infantile HPP presents before 6 months-of-age, often with rickets, failure-tothrive, hypotonia, and muscle weakness, and can be complicated by hypercalcemia, nephrocalcinosis, vitamin $\mathrm{B}_{6}$ dependent seizures, and craniosynostosis [5, 38]. Vitamin $\mathrm{B}_{6}$-dependent seizures and skeletal deterioration predict death from respiratory complications [36]. If there is survival beyond infancy, deciduous teeth are lost prematurely (i.e., before the patient's 5th birthday) because insufficiently mineralized cementum can not anchor their roots to the periodontal ligament [39]. Childhood HPP also has broad-ranging severity, but almost always includes premature loss of primary teeth. Rickets sometimes causes short stature, and skeletal deformities can include bowed legs and bony enlargement near joints due to widened metaphyses. Affected children often manifest some degree of motor impairment and fatigue easily. In 2015, "mild" versus "severe" childhood HPP were distinguished [36]. In occasional cases, childhood HPP presents in the guise of infantile hypophosphatasia shows gracile, deformed, and fractured ribs that contribute to the respiratory compromise that is often lethal for such patients. $\mathbf{d}$ This radiograph of the right knee of a 9-year-old girl with childhood hypophosphatasia shows characteristic findings including areas of osteopenia and osteosclerosis especially in the metaphyseal regions, and marked physeal widening and irregularity of the head of the fibula

chronic recurrent multifocal osteomyelitis, possibly due to marrow edema secondary to pyrophosphate crystal deposition [40]. Adult HPP usually presents during middle age and features osteomalacia, although some patients report a history of rickets and/or early loss of "baby" teeth [41]. Recurrent, poorly healing, metatarsal stress fractures and then pseudofractures are typical skeletal complications. Some of these patients suffer calcium pyrophosphate dihydrate (CPPD) crystal deposition (chondrocalcinosis), $\mathrm{PP}_{\mathrm{i}}$ arthropathy including attacks of pseudogout, or sometimes calcific periarthritis [42]. Odonto-HPP is diagnosed when the only clinical abnormality is dental disease, with radiological and biopsy studies revealing no evidence of rickets or osteomalacia. Figure 2 shows representative radiographic images of the skeleton in these principal forms of HPP.

HPP is a remarkable type of rickets or osteomalacia because circulating levels of calcium, $\mathrm{P}_{\mathrm{i}}$, and vitamin $\mathrm{D}$ metabolites are not low. Instead, there is a block of mineral entry into the skeleton [35].

At this writing, 300 ALPL mutations have been identified in HPP, $70 \%$ of which are missense (http://www. 
sesep.uvsq.fr/03_hypo_mutations.php). ALPL mutations can cause autosomal recessive (AR) or autosomal-dominant (AD) HPP. Perinatal and infantile HPP generally reflect compound heterozygosity for $A L P L$ missense mutations [36], but sometimes there is homozygosity [9]. Childhood HPP reflects either AR or AD inheritance [35, 36]. Adult and odonto-HPP are usually caused by AD inheritance of $A L P L$ alleles with dominant-negative effects $[9,19,36]$.

\section{Mouse Models of HPP}

In the 1990's, two Alpl global KO mouse models for HPP (Alpl $l^{\text {tm1Sor }}$ and $A l p l^{\text {tm1Jlm }}$ ), that differ in the design of the targeting construct, were developed independently by the research groups of Soriano [43] and of Millán [44]. In $A l p l^{\text {tmlSor }} \mathrm{KO}$ mice, the genomic Alpl sequence spanning from the middle of exon 2 to the middle of exon 6 was replaced with a LacZ-Neo cassette to enable expression of $\beta$-galactosidase under control of the endogenous Alpl promoter. These mice had elevated plasma PLP levels and died from seizures caused by diminished hydrolysis of PLP to pyridoxal (PL) and thus deficient PL availability for cells of the central nervous system [45]. Surviving animals manifested dental dysplasia [43]. In contrast, the $A l p l^{\text {tmlJlm }}$ $\mathrm{KO}$ model was generated by inserting a Neo cassette into exon 6. Homozygous animals exhibited vitamin $\mathrm{B}_{6}$-dependent seizures and impaired bone mineralization [44]. Their lifespan averaged $8.8 \pm 2.3$ days on the $129 \mathrm{~J}$ background, and $10.6 \pm 3.4$ days on the $129 \mathrm{~J}, \mathrm{C} 57 \mathrm{Bl} / 6 \mathrm{~J}$ hybrid background. Plasma of Alpl KO mice contains little ALP activity, which comes from the gut [46], whereas heterozygous $\mathrm{Alpl}^{+/-}$mice have approximately $50 \%$ the plasma ALP activity of wild-type (WT) mice and are healthy and fertile [44].

In 1999, these two KO mouse models, Alpl $l^{\text {tm1Sor }}$ and $A l p l^{\text {tmIJlm }}$, were further characterized and compared [28]. Radiographic bone abnormalities appeared at $\sim 10$ daysof-age, and osteopenia and fractures worsened thereafter. Both had elevated urinary PEA and PP $_{i}$ and plasma PLP levels. That same year, Beertsen et al. [47] reported a 2-3 day delay in incisors eruption and onset of mineralization of the mantle dentin within the developing molars of the Alpl $l^{\text {tmlSor }} \mathrm{KO}$ mice. In contrast, the dentin and enamel developed normally, except for some localized hypoplasia. The most conspicuous finding, however, involved the acellular cementum along the molar roots, which deposited as thin and irregularly shaped patches rather than a continuous layer around the base of the periodontal ligament fibers [47]. The Alpl ${ }^{\text {tmlJlm }} \mathrm{KO}$ mice had impaired dentin mineralization in the incisor and molar roots, ranging from a mild delay to severely disturbed dentinogenesis. Subsequently noted were lack of acellular cementum [48, 49] and disrupted organization of the rods and inter-rod structures in the enamel [50]. Also, premature fusion of the coronal suture (craniosynostosis) appeared in these Alpl ${ }^{\text {tmlJlm }}$ KO mice [51]. Figure 3 shows representative radiographic images of their skeletal and dental phenotype. Alpl tmlJlm $^{\mathrm{KO}}$ mice also have an apoptotic thymus, thin descending nerve roots, leukopenia, and gas accumulation in their small intestine [44, 52]. Most studies concerning murine HPP and the preclinical work for EzRT for HPP used Alpl ${ }^{\text {tmlJlm }}$ mice. Accordingly, later, we simply refer to them as the $\mathrm{KO}$ mice.

Now, other Alpl mutant mouse lines have been generated, although their skeletal and dental phenotypes remain to be determined. In 2009, the $A l p l^{A L P L D 1}$ model was produced by ENU mutagenesis and carries an $A$ to $G$ mutation at nucleotide (nt) position 326 in exon 5 [53]. This causes an Asp to Gly change at residue 109. In 2012, Sabrautzki et al. reported new mouse models for various metabolic bone diseases produced by the Munich ENU Mutagenesis Project [54], including phenotypes associated with lowered plasma ALP activity due to mutations in Alpl. Alpl $l^{B A P 023}$ carries a missense $\mathrm{T}$ to $\mathrm{G}$ mutaton in exon 7 at nt 755 (Leu to Pro at residue 251). Alpl $l^{B A P 026}$ has a splice-site mutation in intron 9. $A l p l^{B A P 027}$ carries a $\mathrm{T}$ to A mutation in exon 10 at nt 1194 (Ile to Asn at residue 395). $A l p l^{B A P 032}$ has an $\mathrm{A}$ to $\mathrm{G}$ mutation in exon 11 at nt 1217 (Asp to Gly at residue 406). The homologous mutation had been found in an HPP patient. $\mathrm{Alpl}^{\mathrm{SAPOO7}}$ has an A to $\mathrm{G}$ point mutation in exon 12 at $\mathrm{nt} 1357$ (Thr to Ala at residue 453).

Currently, mouse models of adult HPP are receiving attention. In 2007, the Gena 328 mouse, $A l p l^{H p p}$, from ENU mutagenesis exhibited autosomal semi-dominant adult HPP [55]. A point mutation at the splice site for exon 8 produced a truncated, inactive TNAP having 276 residues rather than the 525 WT residues. However, some correct splicing was detected, suggesting the mutation is hypomorphic. These mice have low plasma ALP activity and late-onset skeletal abnormalities, but a normal life span and no epilepsy.

The first murine model of odonto-HPP harbors a missense mutation (c.346G $>$ A) that changes codon 116 from Ala to Thr as identified in a kindred with AD odonto-HPP [56]. These $A l p l^{+/ A 116 T}$ mice have $\sim 50 \% \mathrm{WT}$ plasma ALP activity and no differences versus WT mice in litter size, survival, or body weight. Their postcranial skeleton is normal radiographically, including no differences in femur length, cortical or trabecular structure or mineral density, or mechanical properties. However, their alveolar bone has radiolucencies and resorptive lesions and osteoid accumulation on the crest. Non-significant changes in acellular cementum seem not to affect periodontal attachment, although circulating ALP activity correlates significantly with incisor cementum thickness. 

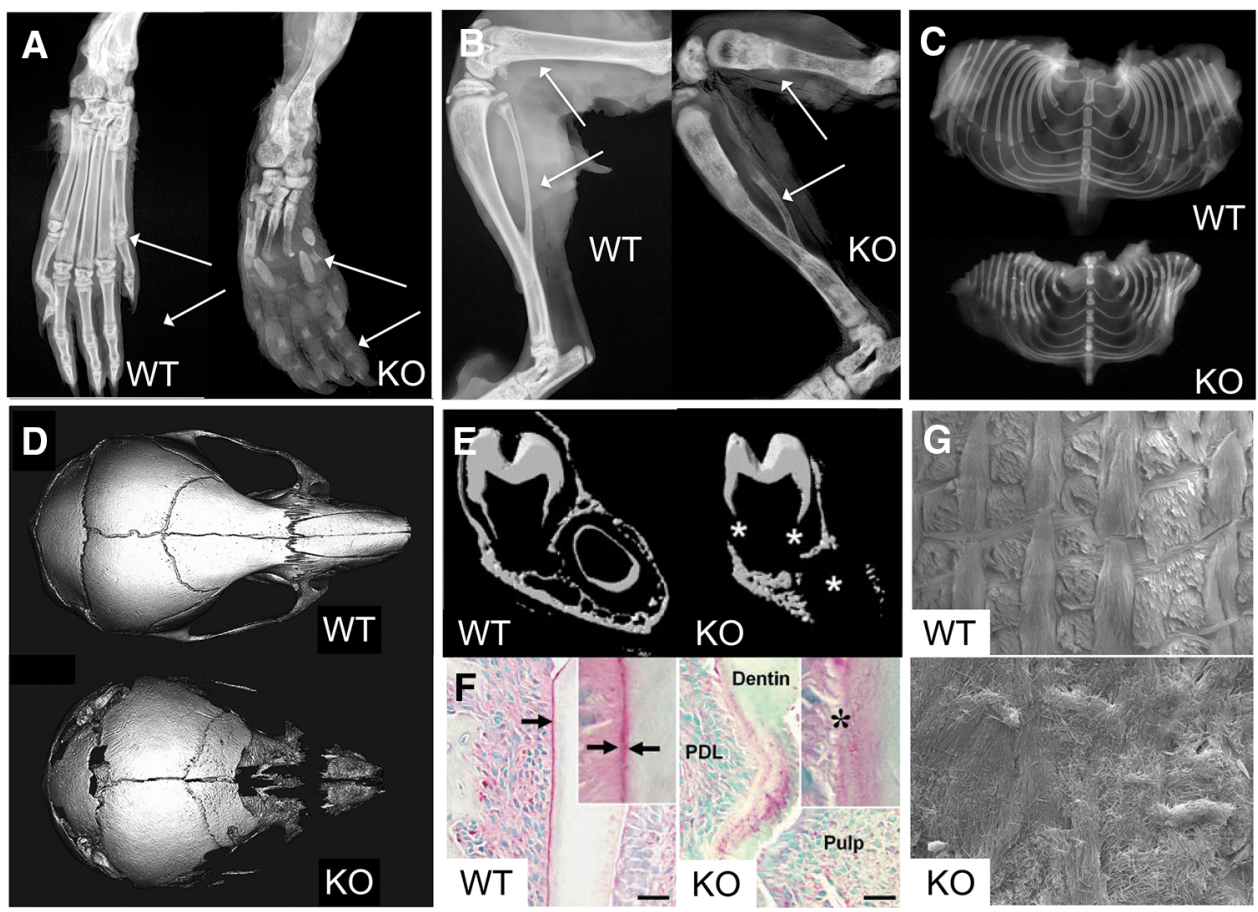

Fig. 3 Phenotype of the $A l p l^{-/-}$mouse model of infantile HPP. a Xray images of a hind paw of a post-natal day 22 (P22) WT and $A l p l^{-/-}$ knockout (KO) mouse. b X-ray of the femur, tibia, and fibula of a P22 WT and KO mouse. Images from $\mathbf{a}$ and $\mathbf{b}$ were taken from [126] and reproduced with permission from BONE. $\mathbf{c}$ Radiographs of the ribs of a P16 WT and KO mouse. Images taken from [124] and reproduced with permission from the Journal of Bone and Mineral Research. d Micro-CT isosurface images of a P15 WT and KO mouse skull. Multiple cranial vault and facial bones are so severely hypomineralized in P15 that they do not appear on isosurface images calibrated to a bone threshold. The KO skull appears decreased in anteriorposterior length but increased in height when compared to the WT skull, and is more dome-shaped in overall appearance. Images taken from [100] and reproduced with permission from Bone. e Micro-CT demonstrates poorly mineralized molar roots and incisor in 10-dayold KO mice compared with WT, in addition to generalized reduction

Now, two murine models of adult HPP reflect conditional ablation of Alpl in chondrocytes and osteoblasts together (Prxl-Cre; Alp $\left.t^{\text {floxfflox }}\right)$, or in osteoblasts alone (Collal-Cre; Alpt $t^{f l o x / f l o x}$ ) (manuscript in preparation). Their phenotype compared to KO and $A l p l^{+/ A 116 T}$ mice is summarized in Table 1.

\section{Pathophysiology of HPP}

In the skeleton, TNAP is confined to the surface of osteoblasts and chondrocytes, including their shed matrix vesicles (MVs) $[57,58]$ where the enzyme is particularly enriched [59]. In humans and mice with HPP (vide infra), electron microscopy revealed that TNAP-deficient MVs contain hydroxyapatite (HA) crystals, but extravesicular growth of these crystals is blocked (Fig. 4) by the of bone mineralization in the mandible. Images taken from [47] and reproduced with permission from the Journal of Bone and Mineral Research. f Immunohistochemical localization of osteopontin (red, arrows and inset), as a marker for acellular cementum, shows a distinct line of acellular cementum in the WT sample, but an absence of a discrete immunostained layer in a 16-day-old KO mouse. $P D L$ periodontal ligament, $E n-S$ enamel space after decalcification. Magnification bars equal $100 \mu \mathrm{m}$. Taken from [46] and reproduced with permission from the Journal of Dental Research. g Scanning electron microscopy (SEM) analysis of incisors (top) and molars (bottom) of WT and KO mice at 20 days-of-age. The SEM images show well-decussated enamel rods and inter-rod in the molar crowns and crown analogs of incisors of WT mice. Note that there is a lack of rod-inter-rod organization in the $\mathrm{KO}$ mice. Images taken from [48] and reproduced with permission from the Journal of Bone and Mineral Research (Color figure online)

extracellular accumulation of $\mathrm{PP}_{\mathrm{i}}$ [3, 60-62]. Elevated urinary and plasma levels of $\mathrm{PP}_{\mathrm{i}}$ were discovered in the 1960s [63-65]. Indeed, breeding Alpl KO mice to mice deficient in either the extracellular production of $\mathrm{PP}_{\mathrm{i}}$ $\left(\right.$ Enpp $^{-/-}$) or transport extracellularly (ank/ank) of $\mathrm{PP}_{\mathrm{i}}$ normalized extracellular levels of $\mathrm{PP}_{\mathrm{i}}$. This prevented skeletal disease in the double $\mathrm{KO}$ mice, and affirmed $\mathrm{PP}_{\mathrm{i}}$ accumulation as the cause of the rickets/osteomalacia in HPP $[66,67]$. The effect of the double ablation was partial at some skeletal sites, likely reflecting variations of Enppl expression $[62,66]$.

In the KO mice, ATP-dependent ${ }^{45} \mathrm{Ca}$ precipitation was reduced within calvarial osteoblast-derived MVs and attributed to increases within the $\mathrm{MV}$ of $\mathrm{PP}_{\mathrm{i}}$ from impaired hydrolysis [68]. However, TNAP is not only a $\mathrm{PP}_{\mathrm{i}}$ ase but, on MVs, is also a potent ATPase [31, 69]. Indeed, Yadav et al. showed that combined ablation of TNAP and 
Table 1 Murine models of HPP spanning the severity of the disease

\begin{tabular}{lllll}
\hline Manifestations & $\mathrm{Alpl}^{-/-}$ & $\mathrm{Alpl}^{\text {Prxl/Prxl }}$ & $\mathrm{Alpl}^{\text {Coll/Coll }}$ & $\mathrm{Alpl}^{+/ \text {All6T }}$ \\
\hline Seizures & Yes & No & No & No \\
Perinatal death & Yes & No & No & No \\
Rickets or osteomalacia & Yes & Yes & Yes & No \\
Joint defects & Yes & Yes & No & No \\
Alveolar bone hypomineralized & Yes & Yes & Yes & Yes \\
Absence of acellular cementum & Yes & Yes & Yes & No \\
Cellular cementum hypomineralized & Yes & Yes & Yes & Yes \\
Dentin (molar) hypomineralized & Yes & No & Yes & Yes \\
Dentin (incisor) hypomineralized & Yes & Yes & Yes & Yes \\
Enamel defects & Yes & $?$ & $?$ & Yes \\
Craniosynostosis & Yes & No & No & No \\
Nephrocalcinosis & Yes & No & No & No \\
\hline
\end{tabular}

?: not yet studied
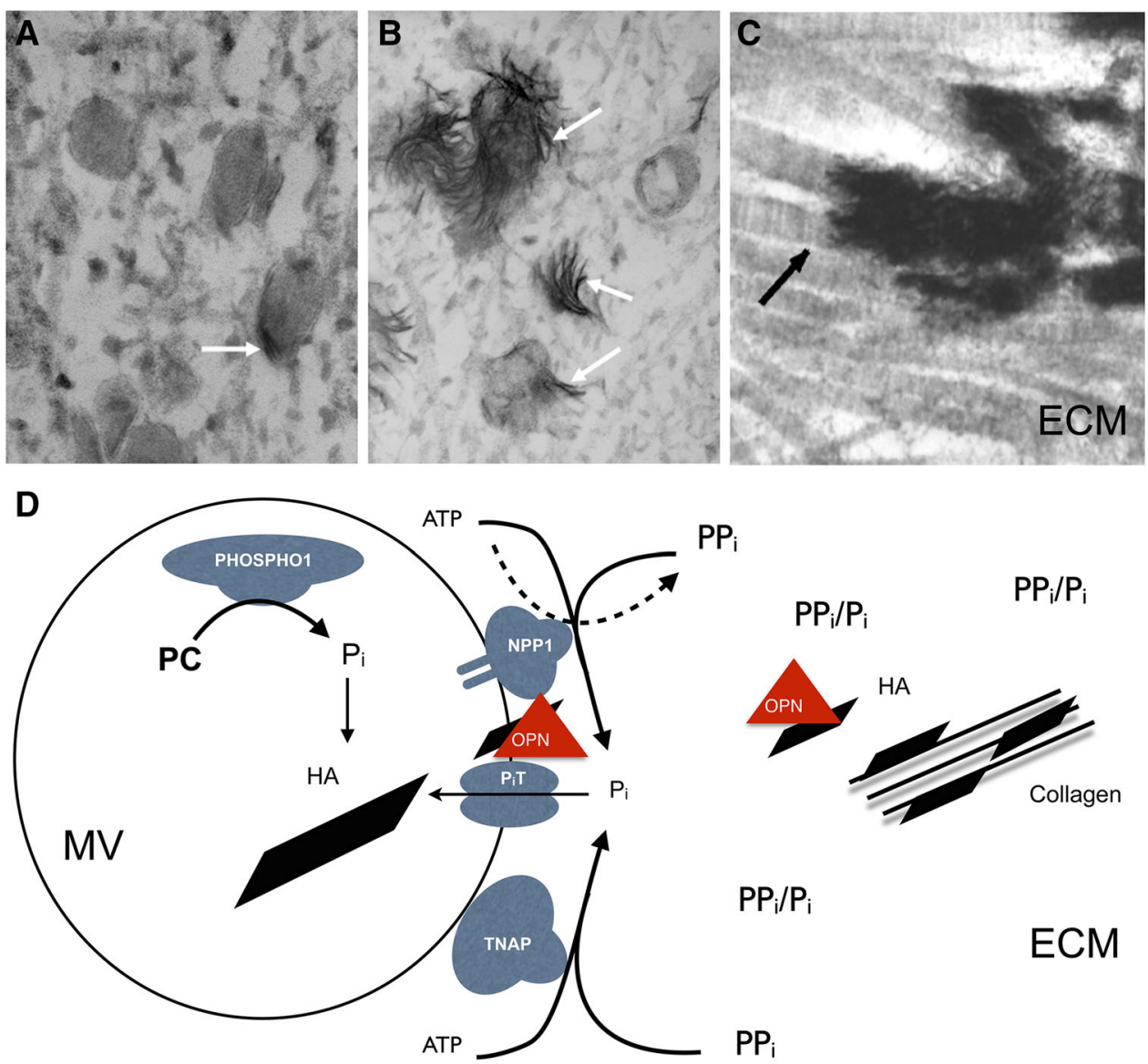

$P_{i}$

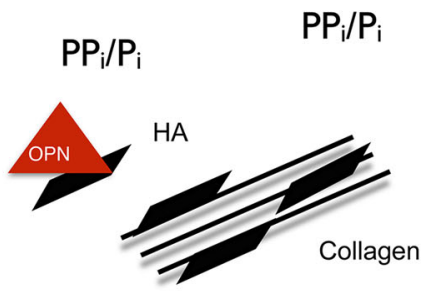

$\mathrm{PP}_{\mathrm{i}} / \mathrm{P}_{\mathrm{i}}$

ECM

$\mathrm{PP}_{\mathrm{i}}$

Fig. 4 Mechanisms of initiation and propagation of skeletal mineralization. Scanning electron microscopy images of matrix vesicles (MV) displaying mineral confined to the interior of the vesicles (a), with mineral breaking through the MV membranes (b) and with mineral propagating onto the collagenous scaffold (c). d Diagram detailing our current understanding of the biochemical bases for these three steps of MV-mediated initiation of biomineralization. MVs appear to initiate HA mineral deposition by accumulation of $\mathrm{P}_{\mathrm{i}}$ generated intravesicularly by the action of PHOSPHO1 on phosphocholine and also via $\mathrm{P}_{\mathrm{i}} \mathrm{T}$-1-mediated incorporation of $\mathrm{P}_{\mathrm{i}}$ generated extravesicularly by TNAP or NPP1. The extravesicular propagation of mineral onto the collagenous matrix is mainly controlled by the pyrophosphatase activity of TNAP that restricts the concentration of this potent mineralization inhibitor and establishes a $\mathrm{PP}_{\mathrm{i}} / \mathrm{P}_{\mathrm{i}}$ ratio conducive for controlled calcification. Additionally, osteopontin (OPN), another potent mineralization inhibitor that binds to HA mineral as soon as it is exposed to the extracellular fluid, also controls the degree of extracellular matrix mineralization. Both elevated levels of $\mathrm{PP}_{\mathrm{i}}$ and phosphorylated OPN are found in HPP mice. ECM extracellular matrix, $H A$ hydroxyapatite, $O P N$ osteopontin 
PHOSPHO1 is additive and leads to the lack of HA crystal formation within MVs, the absence of skeletal mineralization, and embryonic lethality. PHOSPHO1 generates $P_{i}$ inside MVs thus contributing to the initiation of HA mineral formation in the intravesicular space [70]. TNAP is a $\mathrm{PP}_{\mathrm{i}}$ ase crucial for allowing extravesicular growth of $\mathrm{HA}$ crystals, while also generating $\mathrm{P}_{\mathrm{i}}$ from the hydrolysis of $\mathrm{PP}_{\mathrm{i}}$ and acting as an extracellular ATP phosphohydrolase that generates $P_{i}$ in the perivesicular space. Thus, current understanding of TNAP function supports Robison's hypothesis concerning skeletal mineralization [35, 70, 71]. NPP1, the enzyme that when on the cell surface produces $\mathrm{PP}_{\mathrm{i}}$, is also a potent ATPase in the MV microenvironment, and may act as a phosphatase in the absence of TNAP [30, 69-71]. Thus, NPP1 could be a modifier of the HPP phenotype, at least in mice. In fact, PHOSPHO1-deficient mice have increased plasma $\mathrm{PP}_{\mathrm{i}}$ levels caused by reciprocal reduction of TNAP activity and increased NPP1 expression, as well as accumulation in the circulation of phosphorylated OPN, an inhibitor of mineralization that perhaps exacerbates the rickets/osteomalacia and fracturing of HPP. Because PHOSPHO1 modifies the HPP phenotype in KO mice, we have searched for Phosphol gene mutations in patients with HPP-like disease without ALPL mutations, however, thus far with negative results. Accordingly, the hypotheses proposed by Robison for skeletal mineralization $[1,2]$ : (i) TNAP as a $\mathrm{P}_{\mathrm{i}}$-generating enzyme, and (ii) an unknown factor controlling the supersaturated milieu for mineralization (now recognized to be $\mathrm{PP}_{\mathrm{i}}$ ), are validated by current data stemming largely from investigations of HPP [35, 72-75]. Furthermore, we currently appreciate that there are interactions between PHOSPHO1, NPP1, and TNAP during MV-mediated calcification: the first step is a convergence of two independent biochemical pathways: intravesicular $\mathrm{P}_{\mathrm{i}}$ generation by the enzymatic action of PHOSPHO1, and the influx via $P_{i}$ transporters of $P_{i}$ generated in the perivesicular space by the enzymatic actions of TNAP and NPP1 (Fig. 4).

Another natural substrate of TNAP discovered by studying HPP patients is PLP, the major circulating form of vitamin $\mathrm{B}_{6}$. Vitamin $\mathrm{B}_{6}$, mediated by its various vitamers, is a cofactor for at least 110 enzymes. The three vitameric forms, pyridoxal (PL), pyridoxamine (PM), and pyridoxine (PN), can all be phosphorylated by PL kinase to their $5^{\prime}$ derivatives, PLP, PMP, and PNP, respectively [76, 77]. PLP is a coenzyme for the catabolizing of various amino acids, and for decarboxylations necessary for neurotransmitter generation including dopamine, serotonin, histamine, taurine, and gamma-aminobutyric acid (GABA). PLP and PMP are interconvertible through aminotransferases or PMP/PNP oxidase. Removal of $P_{i}$ from PLP to form PL is one important function of TNAP [78]. Only the non-phosphorylated vitamers can enter cells, and once inside the cells, these non-phosphorylated vitamers are converted back to PLP to be used as a coenzyme for various enzymatic pathways. TNAP deficiency increases plasma PLP levels in all HPP patients, but leads to low levels of PL in the circulation in severely affected infants who consequently have insufficient incorporation of PL into the CNS and therefore vitamin B6-dependent seizures $[45,78-80]$. Resembling the $100 \%$ lethality when vitamin $\mathrm{B}_{6}$-dependent seizures occur in infantile HPP [38], KO mice too have $100 \%$ mortality after weaning, always heralded by seizures. TNAP is highly expressed in the developing murine neural tube [81] and certain areas of the mature brain [82]. The absence of TNAP in KO mice is associated with hypomyelination and thinning of spinal nerves, the absence of myelinated axons, and an increased proportion of immature cortical synapses [44, 52, 83]. Matching clinical experience treating vitamin $\mathrm{B}_{6}$-dependent seizures in HPP, injection or ingestion of PL, a hydrophobic form of vitamin $\mathrm{B}_{6}$ that traverses biological membranes temporarily suppresses the epilepsy of $\mathrm{KO}$ mice [43, 44, 52].

PEA is elevated in the blood and urine of patients with HPP [28, 29, 45], but its endogenous origin is uncertain. PEA is a component of the cell-surface glycosylphosphatidylinositol link for proteins, including TNAP. However, an additional or alternative source of PEA may reflect diminished hepatic $O$-phosphorylethanolamine phospholyase (PEA-P-lyase) activity-the enzyme reported to hydrolyze PEA using PLP as a cofactor [84-86]. Because TNAP hydrolyzes extracellular PLP to PL to allow incorporation of PL into cells for the formation of PLP needed as a coenzyme, insufficient PLP inside hepatic cells could increase PEA accumulation. In this regard, the authors began their nearly career-long collaborations in 1979 when they studied a large multigenerational kindred with adult HPP who showed elevated PEA and phosphoserine levels in the urine which correlated inversely with serum total and liver TNAP activity, but not serum bone TNAP activity [87].

TNAP KO mice have high plasma osteopontin (OPN) levels encoded by Sppl, and elevated expression of its RNA in cultured osteoblasts [88-90]. Although the function of OPN is incompletely understood, it anchors osteoclasts to HA by its poly-aspartate sequences, while also binding CD44 and $\alpha_{\mathrm{v}} \beta_{3}$ integrin via its RGD sequence, thus mediating cell signaling and/or migration [91]. OPN is a highly phosphorylated glycoprotein, with 36 serine/threonine phosphorylation sites [92]. This phosphorylation is important because OPN's inhibitory effect on mineral deposition diminishes if $84 \%$ of this covalently bound phosphate is removed [93]. Phosphorylated, but not dephosphorylated, OPN inhibits mineralization in vascular smooth muscle cells [94]. Certain phosphorylated OPN 
peptides also inhibit HA formation in vitro [95], and cause dose-dependent inhibition of mineralization by cultured cells [96]. Extracellular $\mathrm{PP}_{\mathrm{i}}$ levels control OPN expression by cultured osteoblasts $[91,96]$, and high plasma levels of phosphorylated OPN accompany the increased extracellular $\mathrm{PP}_{\mathrm{i}}$ levels in Alpl $\mathrm{KO}$ mice [90]. In turn, $\left[\mathrm{Alpl}^{-/-}\right.$; $S p p 1^{-/-}$] double KO mice have partial improvement of the hypomineralization compared to $\mathrm{Alpl}^{-/-}$KO mice [90]. Hence, phosphorylated OPN accumulation may contribute to the impaired bone mineralization of Alpl $\mathrm{KO}$ mice. Absent TNAP function leads to accumulation of phosphorylated OPN [34]. This suggests that OPN is another substrate of TNAP, and OPN phosphorylation is an additional biochemical pathway in the pathophysiology of murine HPP (Fig. 4). We are currently reviewing the OPN status of HPP patients.

Interestingly, PHOSPHO1-deficient mice also have increased plasma levels of $\mathrm{PP}_{\mathrm{i}}$ and phosphorylated OPN. Here, concurrent ablation of the OPN gene corrects the skeletal disease of Phosphol deficiency [97]. Thus, Alpl and Phosphol deficiency engender similar skeletal phenotypes and comparable changes in $\mathrm{PP}_{\mathrm{i}}$ and $\mathrm{OPN}$ expression levels. However, there is a clear dissociation in the hierarchical roles of these potent inhibitors of mineralization, with elevated $\mathrm{PP}_{\mathrm{i}}$ and phosphorylated OPN levels causing the respective skeletal phenotypes in $\mathrm{Alpl}^{-/-}$and Phosphol ${ }^{-/-}$mice.

Other biological roles for TNAP are now being explored inspired by studies concerning intestinal ALP in protection of the gut mucosa and regulation of the gut microbiota via detoxification of bacterial endotoxins, especially di-phosphoryl-lipopolysaccharide (LPS) and pro-inflammatory ATP [98-100]. Lei et al. [33] showed in hamsters that LPS detoxification by TNAP conditions uterine receptivity for implantation and decidualization, while protecting the uterus and pregnancy against bacterial infection. High circulating TNAP activity in neonates enhances their high plasma levels of anti-inflammatory adenosine, produced by the dephosphorylation of pro-inflammatory ATP [31]. Furthermore, TNAP is one of three enzymes involved in purine metabolism, contributing anti-nociceptive adenosine for murine somatosensory dorsal root ganglia neurons and the dorsal spinal cord [32]. Altered purinergic signaling in Alpl KO mice could result from an increased ATP/adenosine ratio caused by TNAP deficiency. Such changes may contribute to the seizures, hyperalgia, and allodynia seen in $\mathrm{Alpl} \mathrm{KO}$ mice, and perhaps patients with severe HPP (Fig. 5).

\section{What We Don't Yet Understand About HPP}

Premature fusion of cranial sutures (craniosynostosis) in HPP and other forms of rickets may seem counter-intuitive and remain unexplained. Patients with severe HPP

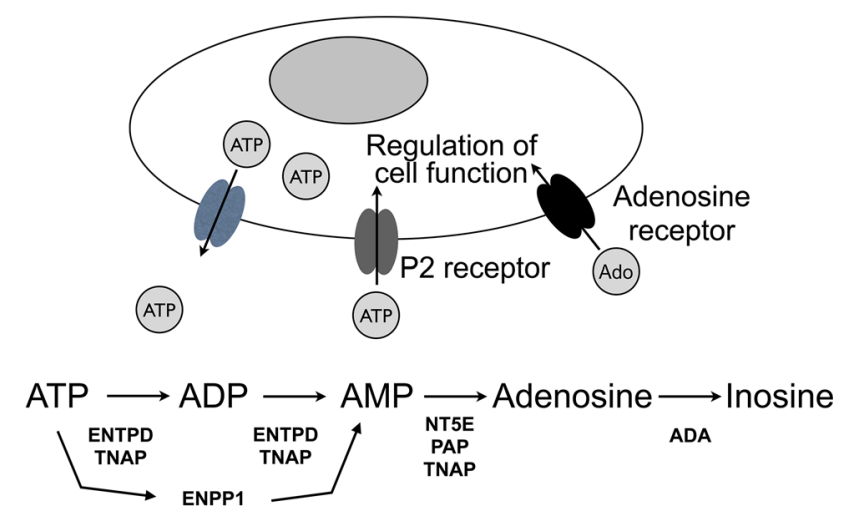

Fig. 5 Enzymes involved in the catabolism of ATP to form adenosine, and thus regulate the ATP/adenosine ratio important for purinergic signaling. ENPP1 ectonucleotide pyrophosphatase/phosphodiesterase, ENTPD/CD39 ectonucleotide triphosphate diphosphohydrolase, NT5E/CD73 ecto-5'-nucleotidase, $P A P$ prostatic acid phosphatase, $A D A$ adenosine deaminase, TNAP tissue-non-specific alkaline phosphatase

receiving asfotase alfa still often require craniotomies [101] to relieve intracranial pressure. However, asfotase alfa [102] and ChimAP [103] (a soluble chimeric form of human ALP), both can prevent craniosynostosis, at least in mice (vide infra), if treatment starts at birth. So, prevention of craniosynostosis may depend on the time of initiation of the treatment, although there are data to indicate that in humans craniosynostosis may begin during embryonic life [104]. Thus, clarifying the onset and mechanism of craniosynostosis may help design interventions at a developmental stage when enzyme replacement may not be feasible in patients.

While the role of TNAP in the skeleton seems well understood, little is known about its function in the kidney, despite reference to this ALP isozyme as liver/bone/kidney type ALP. Expression of TNAP in the kidney may seem counter-intuitive because TNAP hydrolyses $\mathrm{PP}_{\mathrm{i}}$, a potent mineralization inhibitor that could help prevent kidney stones. In fact, reduced urinary $\mathrm{PP}_{\mathrm{i}}$ predisposes to nephrolithiasis [105]. $\mathrm{PP}_{\mathrm{i}}$ :creatinine ratios were reduced in 107 patients with recurrent calcium kidney stones [106]. $\mathrm{PP}_{\mathrm{i}}$ levels in urine are $>10 \mu \mathrm{M}$ compared to plasma concentrations of approximately 1-6 $\mu \mathrm{M}$ that mainly arise from liver metabolism [107]. Intravenous ${ }^{32} \mathrm{PP}_{\mathrm{i}}$ is rapidly hydrolyzed in plasma, with $\mathrm{PP}_{\mathrm{i}}$ also being filtered at the glomerulus and subject to further hydrolysis within the kidney; $<5 \%$ of intravenous ${ }^{32} \mathrm{PP}_{\mathrm{i}}$ appears in urine. These data indicate that $\mathrm{PP}_{\mathrm{i}}$ in the kidney likely originates locally. Thus, nephrocalcinosis despite high urinary concentrations of $\mathrm{PP}_{\mathrm{i}}$ in severely affected babies with HPP could seem puzzling, but their severe hypercalcemia and hypercalciuria is likely the key factor. Interestingly, children and adults with HPP are often hyperphosphatemic with increased TmP/GFR, suggesting kidney TNAP plays a role in $\mathrm{P}_{\mathrm{i}}$ excretion [36]. 


\section{Supportive Management of HPP}

HPP management has been, until very recently, supportive [9]. Bone-targeted enzyme replacement therapy (asfotase alfa, now Strensiq ${ }^{\mathrm{TM}}$ ) was approved for HPP in Japan (July, 2015), and for pediatric-onset HPP in Canada (August, 2015), Europe (August, 2015), and the USA (October, 2015). Supportive treatment includes hydration and restriction of dietary calcium and perhaps administration of calciuretics for infants with hypercalcemia and hypercalciuria $[35,36]$. Management of the respiratory complications of perinatal and infantile HPP may be complex as multiple factors compromise their pulmonary function [108]. Vitamin $\mathrm{B}_{6}$-dependent seizures can respond temporarily to pyridoxine administration. Craniosynostosis may need surgical intervention. Fractures can mend, but often slowly and requiring prolonged casting or stabilization with intramedullary hardware. Femoral pseudofractures can also respond to intramedullary rodding [109]. Dental manifestations can be helped by a knowledgeable dentist.

\section{Targeting TNAP to Bone Mineral}

Bolstered by insight derived from discovery of elevated plasma PLP levels in HPP [45] that predicted TNAP is cellsurface anchored, intravenous administration of ALPs to HPP patients was attempted to decrease extracellular $\mathrm{PP}_{\mathrm{i}}$ levels and thereby improve skeletal mineralization. However, experience with such EzRT, including plasma from patients with Paget bone disease containing high bone TNAP activity, proved unsuccessful [110]. A 6-month-old girl with worsening infantile HPP repeatedly given intravenous infusions of TNAP-rich plasma obtained by plasmapheresis from two men with Paget bone disease showed circulating ALP activity with a half-life of $\sim 2$ days that persisted during a 5-week period of six ALP infusions. Sequential radiographic studies were interpreted as showing arrest of worsening rickets with slight remineralization of metaphyses, although urinary levels of PEA and $\mathrm{PP}_{\mathrm{i}}$ seemed unaltered [110]. However, three subsequent patients deteriorating from infantile HPP [111] and given similar infusions of Paget plasma showed no radiographic or other benefit. Discouraging findings also occurred with attempted EzRT using purified human liver TNAP [112] and purified PLAP [113]. The cumulative findings indicated necessity for increasing TNAP activity in situ in the skeleton to reverse the pathophysiology of HPP. This hypothesis was supported in 2003 and 2007 by rescue with radiographic improvement demonstrated by two unrelated girls with life-threatening infantile HPP following attempts to transplant healthy mesenchyme- derived marrow cells, hoping TNAP-replete donor osteoblasts or chondrocytes might engraft in their skeletons [114, 115]. Subsequently, a woman with adult HPP carrying the most common American ALPL mutation seemed to benefit from teriparatide injections given to increase TNAP biosynthesis by her osteoblasts [116]. Then, anabolic treatment with parathyroid hormone 1-34 or 1-84 benefitted some adults with HPP [117-119], but not others [120, 121]. Parathyroid hormone therapy is not sanctioned for children, because osteosarcoma appeared in growing rats given teriparatide [122]. Evaluation of anti-sclerostin antibody (BPS804) therapy, which has been reported to increase bone-specific ALP when administered to healthy post-menopausal women [123] (www.clinicaltrials.gov identifier NCT01406977), was not carried forward. Anabolic approaches may favor patients with heterozygous $A L P L$ mutations, because the WT ALPL allele is intact for upregulation; however, it will probably not be useful for severe AR HPP with at best "more of a bad enzyme."

In 2005, Enobia Pharma, Montreal, Canada bio-engineered and then expressed in Chinese hamster ovary (CHO) cells a first-in-class mineral-seeking recombinant TNAP to treat HPP. This biologic reflected in tandem the coding sequences for (i) soluble human TNAP, by excluding the hydrophobic C-terminal GPI anchoring motif (i.e., soluble TNAP: sALP), (ii) the Fc region of human IgG gamma-1 $(\mathrm{Fc})$ to facilitate purification and prolong the circulating half-life, and (iii) ten acidic aspartate residues $\left(D_{10}\right)$ for selective drug delivery to bone [124-126]. The resulting 726-amino acid fusion protein was initially designated sALP-FcD 10 to indicate its different domains (Fig. 6), renamed ENB-0040 when produced under Current Good Manufacturing Practice (cGMP), and asfotase alfa after clinical trials began. Alexion Pharmaceuticals, Cheshire, CT acquired Enobia Pharma in 2012. Asfotase alfa is now also called Strensiq ${ }^{\mathrm{TM}}$.

\section{Preclinical Evaluation of Bone-Targeted EzRT for HPP}

Preclinical testing of $\mathrm{SALP}-\mathrm{FcD}_{10}$ primarily involved Alpl $^{\text {tmIJlm }}$ (KO) mice. Pharmacokinetics (PK) and tissue distribution evaluations included newborn and adult mice and comparisons of different routes of administration [127]. Histochemical staining confirmed localization and catalytic activity of SALP-FcD 10 in bone tissue (Fig. 6).

The first study involved newborn KO mice given subcutaneous (SC) injections for 15 days, then investigated with micro-computed tomography $(\mu \mathrm{CT})$ of the calvarium and proximal tibial growth plate [127]. At $2 \mathrm{mg} / \mathrm{kg}$ daily, general appearance, body weight, and tail length improved with normal growth. At $8.2 \mathrm{mg} / \mathrm{kg}$ daily, body weight was 


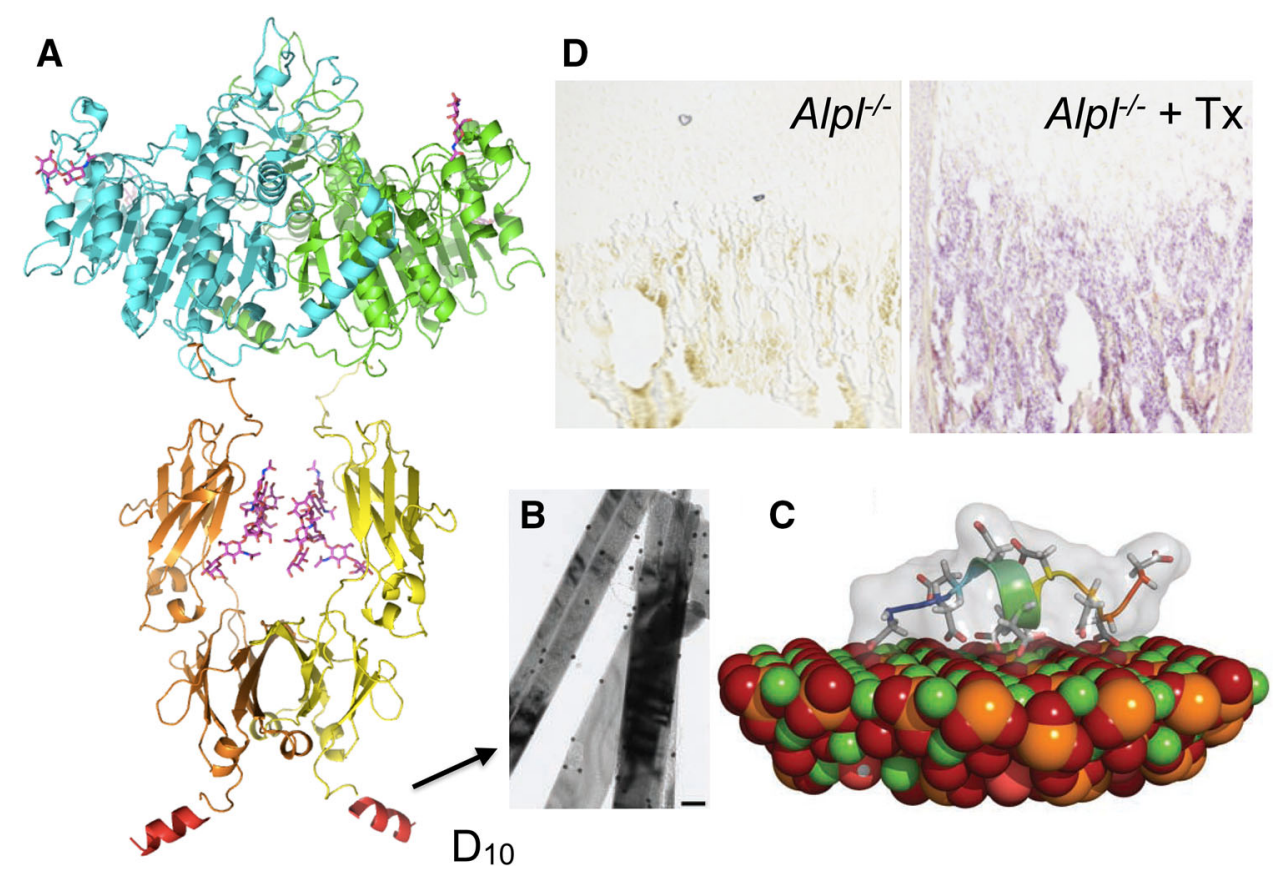

Fig. 6 Structure and binding of asfotase alfa to bone mineral. a Three-dimensional modeling of ENB-0040. The model shows rigid ALP and $\mathrm{Fc}$ modules connected by a highly flexible linker. The terminal poly-Asp region is exposed on the opposite site of the ALP module. The whole structure is dimeric that conforms to the preferred oligomeric state of the ALP as well as the Fc region of the antibody. The three active site metal ions (two $\mathrm{Zn}^{2+}$ and one $\mathrm{Mg}^{2+}$ ) are marked with blue spheres. b Transmission electron micrograph showing the binding of $\mathrm{sALP}-\mathrm{FcD}_{10}$ to synthetic hydroxyapatite crystals as

greater than control mice, and plasma $\mathrm{PP}_{\mathrm{i}}$ concentrations were normal. sALP-FcD ${ }_{10}$ minimized hypomineralization in the feet and reduced the number of mice with severely dysmorphic rib cages. The hind limbs appeared healthy in all treated animals [127]. A 52-day study of daily SC injections of $8.2 \mathrm{mg} / \mathrm{kg}$ also showed normal plasma PL and calcium concentrations and prevention of skeletal defects and epilepsy with good survival [127]. Hypomineralization of dentin and alveolar bone was also prevented and acellular cementum now formed properly [48, 49]. Immunohistochemical staining for OPN revealed unremarkable, rather than absent, acellular cementum on root surfaces [48]. The KO mouse dentin defect results from inability of MV-initiated mineralization foci to expand into a mineralization front, and varies from delayed mineralization to arrest of mantle dentin mineralization together with lack of circumpulpal dentin and odontoblast differentiation defects [49]. The OPN accumulation likely contributes to the impaired mineralization of mantle dentin. Early treatment with sALP- $\mathrm{FcD}_{10}$ enabled dentinogenesis and molar mineralization.

Then, the relationship was defined between sALP-Fc- $\mathrm{D}_{10}$ doses and therapeutic responses after 43 days [128] (Fig. 7). Endpoint assessments included survival, body weight, tibial revealed by immunogold labeling (inset is control incubation without SALP-FcD $\mathrm{F}_{10}$ showing an absence of gold-particle labeling). Magnification bar equals $100 \mathrm{~nm}$. c RosettaSurface-simulated model of $\mathrm{D}_{10}$ binding to a calcium-rich plane of the [100] crystallographic face of hydroxyapatite. d Histochemical staining for ALP activity in long bones of an ENB-0040-treated Alpl KO mouse compared with an age-matched untreated $\mathrm{Alpl} \mathrm{KO}$ mouse. Images shown in $\mathbf{b}$ and $\mathbf{c}$ were taken from [46] (Color figure online)

and femoral length, and bone mineralization in the feet, rib cage, and lower limbs assessed radiographically. Radiographs, $\mu \mathrm{CT}$, and histomorphometry evaluated skeletal mineralization. Daily dose correlated clearly with the percentage of normal feet, rib cages, and lower limbs. An effective dose was established for $80 \%$ of the mice $\left(\mathrm{ED}_{80}\right)$ of $\sim 3.2, \sim 2.8$, and $\sim 2.9 \mathrm{mg} / \mathrm{kg} / \mathrm{day}$ for feet, rib cage, and lower limbs, respectively. The $\mathrm{ED}_{80}$, along with serum ALP activity and SALP-FcD 10 PK data were used to estimate the minimum effective dose for these $\mathrm{KO}$ mice.

Further studies then validated the mineral targeting, including to sites notorious for poor vascularity, e.g., the enamel organ during tooth development. Untreated $\mathrm{KO}$ mice showed with scanning electron microscopy disorganization of the rod and inter-rod structures of enamel. Histology revealed enamel hypomineralization both in molars and incisors, loss of polarization of ameloblasts important for enamel matrix formation, and even absent enamel. What was now called ENB-0040 reached the enamel organ during its secretory and maturation phases [50]. $\mu \mathrm{CT}$ showed, with treatment to age 23 days, dosedependent improvements of absolute and relative enamel volumes. Notably, odonto-HPP typically manifests the mildest reductions of serum ALP levels [35], usually 

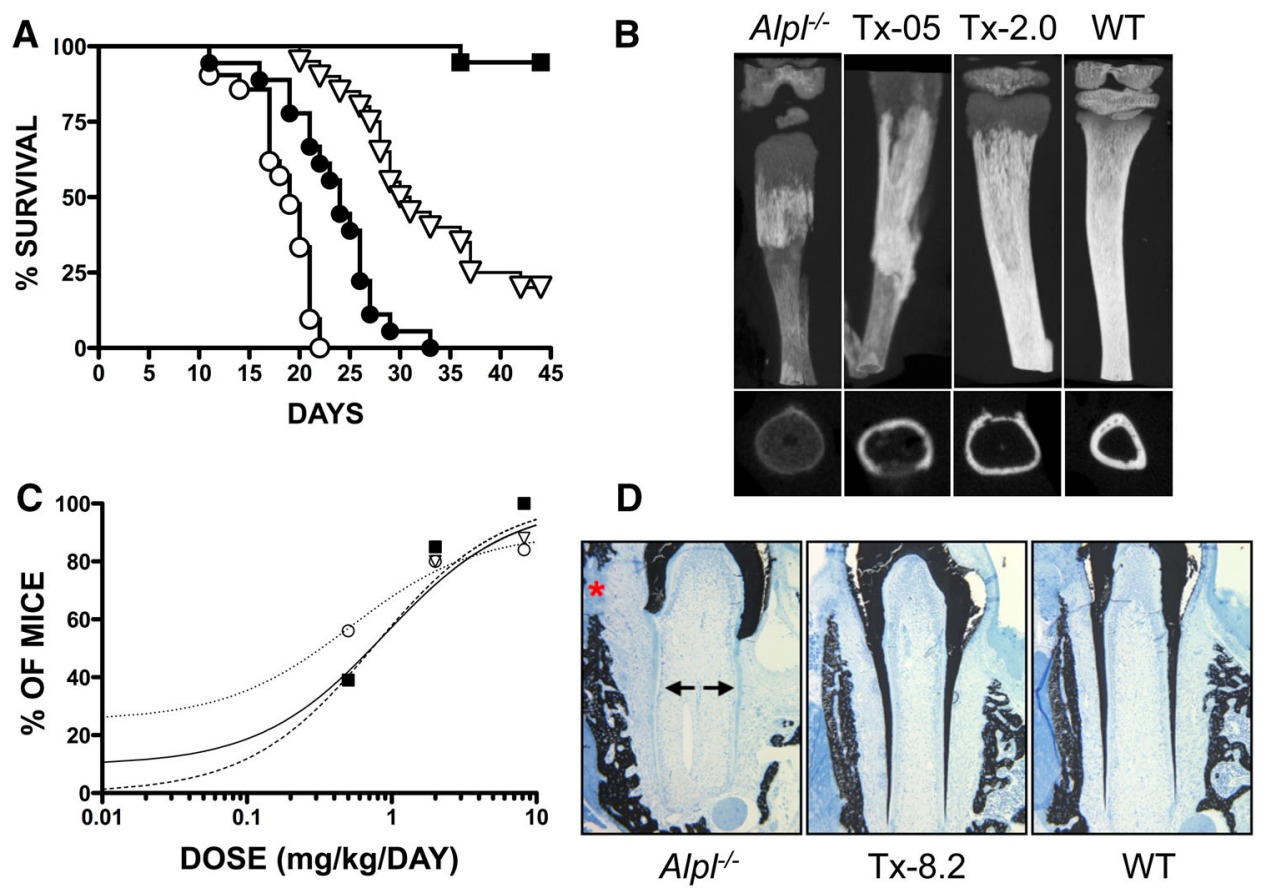

Fig. 7 Preclinical efficacy of asfotase alfa. a Percentage survival of $\mathrm{Alpl}^{-/-}$mice receiving either vehicle (white circle) or escalating doses of asfotase alfa, i.e., Tx-0.5 (black circle), Tx-2.0 (white downpointing triangle), or Tx-8.2 (black square). $\mathbf{b} \mu \mathrm{CT}$ images of tibiae of the 22-day-old $\mathrm{Alpl}^{-/-}$mice treated with vehicle, Tx-0.5, Tx-2.0, and untreated WT mice. The images clearly show improved tissue mineral density and callus formation at the site of fractures in the treated mice. Transaxial views at the bottom. $\mathbf{c}$ Percentage of $\mathrm{Alpl}^{-/-}$

mice considered normal as a function of asfotase alfa dose for feet (black square), rib cage (white down-pointing triangle), and lower limbs (white circle). d Asfotase alfa treatment maintains complete mineralization of all molar dentin as well as the surrounding alveolar bone such that no mineralization differences are seen between the molar teeth and bone of the treated $\mathrm{Alpl}^{-1-}$ mice $(8.2 \mathrm{mg} / \mathrm{kg} / \mathrm{day})$ compared with WT mice. Images taken from [128] with permission from BONE

explained by dominant inheritance of a single mutated $A L P L$ allele [19], and reveals that tooth formation, especially cementogenesis, is the developmental process most sensitive to TNAP function, involving changes in the local $\mathrm{P}_{\mathrm{i}} / \mathrm{PP}_{\mathrm{i}}$ ratio [129, 130]. ENB-0040 treatment preserved acellular cementum formation in the KO mice, supporting this premise [48] and that the structural integrity of enamel by the enamel organ is directly regulated by extracellular $\mathrm{PP}_{\mathrm{i}}$ concentrations [50]. TNAP is highly expressed in mature odontoblasts, and the molar and incisor roots of $\mathrm{KO}$ mice feature dentin hypomineralization ranging from mild to severe. Lack of mantle dentin mineralization accompanies disordered and dysmorphic odontoblasts. However, in $\mathrm{KO}$ mice, the formation of, initiation of mineralization within, and rupture of MVs in dentin matrix are not compromised. ENB-0040 corrected the defective dentin mineralization in the molar roots [49]. Liu et al. [51] showed that these mice by age 3 weeks have craniofacial shape abnormalities suggestive of limited anterior-posterior head growth with craniosynostosis (i.e., bony coronal suture fusion). $\mu \mathrm{CT}$ isosurface images showed ENB-0040 $8.2 \mathrm{mg} /$ $\mathrm{kg} / \mathrm{day}$ from birth prevented at age 15 days craniofacial bone mineralization defects and premature suture fusion. In untreated $\mathrm{KO}$ mice, multiple cranial vault and facial bones lacked adequate mineralization on $\mu \mathrm{CT}$ that was not evident in the treated mice. Digital caliper linear measurements demonstrated that treatment improved nose length, nasal bone length, and frontal bone length [102].

\section{Clinical Trials Using Mineral-Targeting TNAP in Pediatric HPP}

In June 2008, an Investigational New Drug (IND) application to test ENB-0040 for HPP patients was filed by Enobia Pharma. Initial dosing was based partly on (i) doseresponse data in KO mice [128], (ii) efficacy observed in treated mice that achieved an equivalent to serum ALP activity in the range of $2400-6000 \mathrm{U} / \mathrm{L}$; (iii) the No-Observed-Adverse-Effect Level (NOAEL) in more sensitive species (rats and monkeys) established in 1-month IV toxicology studies, and 1-month IV/SC bridging and tolerability studies in rats; and (iv) a safety factor of 10 applied to the NOAEL. 
The first results in HPP patients were from an openlabel, multicenter center, dose-escalating phase 1 study of the safety, tolerability, and pharmacology of ENB-0040 in six adults with HPP (www.clinicaltrials.gov identifier NCT00739505). They received one dose iv of $3 \mathrm{mg} / \mathrm{kg}$, and then 1 or $2 \mathrm{mg} / \mathrm{kg}$ sc once weekly for 3 weeks.

The first full report concerning HPP treatment was from an open-label, multicenter, international study published in 2012 [9]. It evaluated the safety, tolerability, bioavailability, PK, pharmacodynamics, and efficacy of asfotase alfa given for nearly 1 year to infants and young children $\leq 3$ years-of-age with life-threatening perinatal and infantile HPP. Before treatment, one 3-year-old girl had lost nearly all radiographically apparent skeletal mineral. The Supplementary Appendix to that paper provides a detailed description of each patient [9]. Efficacy assessments included changes in radiographic scales to evaluate the characteristic skeletal findings, gross and fine motor function, cognitive development, and pulmonary complications and their management. Asfotase alfa was administered as a single iv infusion of $2 \mathrm{mg} / \mathrm{kg}$, followed by sc injections of $1 \mathrm{mg} / \mathrm{kg}$ thrice weekly for 24 weeks, with an extension study thereafter. The sc dose could be increased up to $3 \mathrm{mg} / \mathrm{kg}$ for worsening failure-to-thrive, deteriorating pulmonary function, or no radiographic evidence of skeletal improvement [9]. Of eleven recruited patients, parents withdrew one because she had a moderate adverse reaction during the iv infusion. One infant who completed the first 6 months of treatment died soon after from pneumonia and sepsis judged unrelated to the study drug. Of the nine patients treated for 1 year, four represented perinatal HPP and five represented infantile HPP. Typically, serum calcium levels were elevated (most had nephrocalcinosis), and dietary calcium had been restricted in all but one patient. During treatment, substantial radiographic improvement in skeletal abnormalities was documented at week 24 in all but one patient, with continued healing through week 48 . The girl with the most extreme skeletal disease eventually improved with calcification apparent after 9 months of therapy and the delay probably reflecting her profound deficit of skeletal mineral. The radiographic improvement is illustrated for the oldest patient (3 years old) (Fig. 8), and for the youngest patient ( $<1$ month old) (Fig. 9). Positive mineral balance throughout the skeleton was obvious radiographically, sometimes after several weeks or months, and involved diffusely membranous as well as endochondral bone. Symptomatic hypocalcemia from "hungry-bones" did not occur, but serum calcium decreased in some patients, consistent with improved uptake of calcium into mineralized bone. Increases in serum parathyroid hormone levels called for liberalization of dietary calcium intakes [9]. Deciduous teeth erupted in all the patients during therapy, with only one patient subsequently having HPP-related tooth loss [9]. Management of perinatal HPP in particular is critically dependent on early diagnosis [131]. An important concern is that some clinical laboratories do not flag as abnormal low serum ALP and this can delay the diagnosis and increase the risk of severe respiratory morbidity. Institution of EzRT should also not be delayed in order to correct any vitamin D deficiency-this can be accomplished contemporaneously if necessary.

Subsequently, asfotase alfa was given for 5 years to 12 children who were 5-12 years of age at study entry and substantially impaired by HPP [132]. Two radiographic scales to quantitate HPP skeletal disease documented rapid and significant improvement at 6-months of treatment, including comparisons to serial radiographs from similarly affected historical controls. Further improvements included patient growth, strength, motor function, and agility that achieved normal values for age- and gender-matched peers and were sustained at 5 years of therapy. Pain and disability resolved for most patients [132]. Mild-to-moderate injection site reactions were common, and sometimes associated with lipohypertrophy. Low titers of anti-asfotase alfa antibodies were noted in all. No evidence emerged for clinically significant ectopic mineralization or resistance to the treatment [132].

\section{Future Treatments for HPP}

Kiffer-Moreira et al. recently evaluated ChimAP in KO mice. ChimAP is a chimeric ALP engineered by substituting the flexible crown domain of human IAP by that of human PLAP [133]. A clinical study is currently underway to assess ChimAP for treating acute kidney injury (www. clinicaltrials.gov identifier NCT02182440). Daily SC injections of ChimAP to KO mice at doses of 1,8 , or $16 \mathrm{mg} / \mathrm{kg}$ from birth to age 53 days were associated with normal lifespan and body weight and prevention of vitamin B6-dependent seizures at $16 \mathrm{mg} / \mathrm{kg} / \mathrm{day}$ [103]. Radiographs, $\mu \mathrm{CT}$, and histological analyses documented sustained mineralization of cortical and trabecular bone and secondary ossification centers in long bones. Craniosynostosis was prevented, and no evidence emerged of ectopic calcification by radiography and histology of the aorta, stomach, kidneys, or lungs [103]. AM Pharma (Bunnik, The Netherlands) has recently received FDA and EMA orphan drug designation for investigation of ChimAP (RecAP) for HPP. Daily sc injections of asfotase alfa are required to prevent HPP in mice, whereas nearly daily or thrice weekly sc injections are used to treat HPP patients. Viral vector delivery of mineral-targeting TNAP by this type of gene therapy might be an alternative to repetitive injections. 

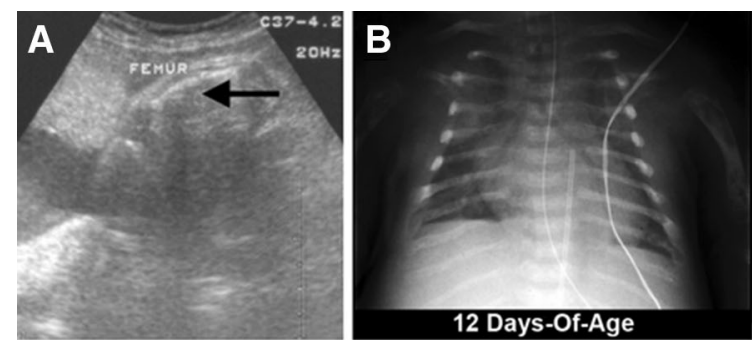

12 Days-Of-Age

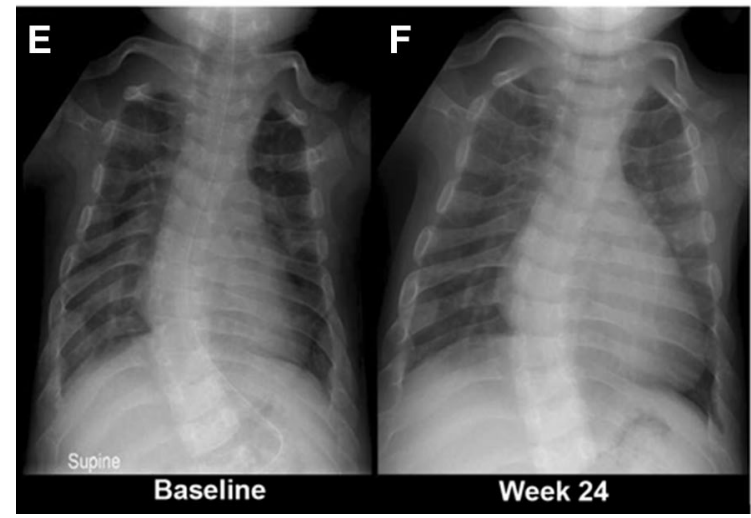

Fig. 8 Efficacy of asfotase alfa treatment in a 36-month-old girl (at therapy baseline) with life-threatening HPP. a She has a short, bowed femur detected in utero by ultrasound. b At 12 days-of-age, her chest radiograph showed thin, osteopenic ribs with lytic areas and fractures. c, d Images of the skull before and after 24 weeks of ENB-0040 treatment. Note the severe pan-suture closure, including a marked increase in "digital" markings ("beaten-copper" appearance). e The

In 2011, Yamamoto et al. [134] demonstrated that a single sc iv injection of a lentiviral vector expressing mineral-targeting TNAP at birth permanently increased plasma TNAP levels in KO mice that survived more than 10 months and had normal physical activity, healthy appearance, no epileptic seizures, and radiographs showing significantly improved or preserved skeletal mineralization using this gene therapy. Also in 2011, Matsumoto et al. [135] demonstrated similar treatment effects, but using the adeno-associated virus serotype 8 (AAV8) vector that is more promising than lentiviral vectors for clinical trials. They expressed mineral-targeted TNAP and soluble, nontargeted TNAP tagged with the FLAG epitope. A single IV injection of $5 \times 10^{10}$ vector genomes of either TNAP into $\mathrm{KO}$ mice at day 1 of life prolonged survival and prevented the skeletal abnormalities, suggesting that sustained ALP activity in the circulation at some threshold level may prevent the manifestations of HPP.

In 2012, Sugano et al. [136] demonstrated the feasibility of fetal gene therapy for HPP by giving KO mouse fetuses, at 15 days gestation, a single transuterine intraperitoneal injection of AAV serotype 9 (AAV9) expressing mineraltargeted TNAP. After birth, these mice showed normal weight gain and seizure-free survival for at least 8 weeks.
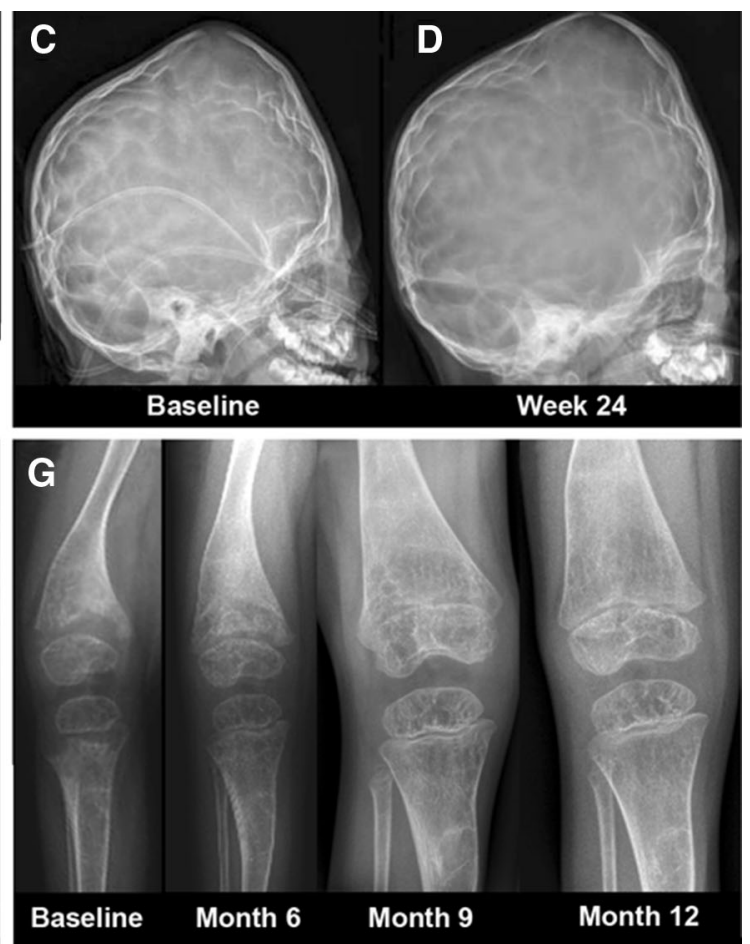

ribs at baseline were osteopenic and had fracture deformities with thin cortices. f By week 24 of treatment, the ribs were wider and better mineralized with sharper cortical margins and less deformity. g Improvement of the rickets with therapy is apparent. Images taken for the online supplementary data in [9] and reproduced with permission from The New England Journal of Medicine

ALP activities in plasma and bone were consistently high, and sustained mineralization was demonstrated on radiographs of the chest and forepaw.

Hence, viral vector delivery of mineral-targeted TNAP has potential to treat HPP with significantly reduced frequency of injections and cost of treatment.

\section{Concluding Remarks}

There has been substantial progress during the past decade in understanding TNAP and therefore in treating HPP patients. Clinical trials of EzRT using asfotase alfa (now approved as Strensiq ${ }^{\mathrm{TM}}$ in Japan, Canada, Europe, and the USA generally for pediatric-onset HPP) have shown skeletal, respiratory, and functional improvement as well as prevention of seizures in the most severe perinatal and infantile forms of the disease and attainment of good health in survivors of infantile HPP and with severe childhood HPP. Ongoing clinical trials are revealing aspects of HPP that we do not yet fully understand, such as its treatable muscle weakness, or that seemingly cannot be prevented such as craniosynostosis. Now that life-threatening and debilitating pediatric HPP is treatable using asfotase 

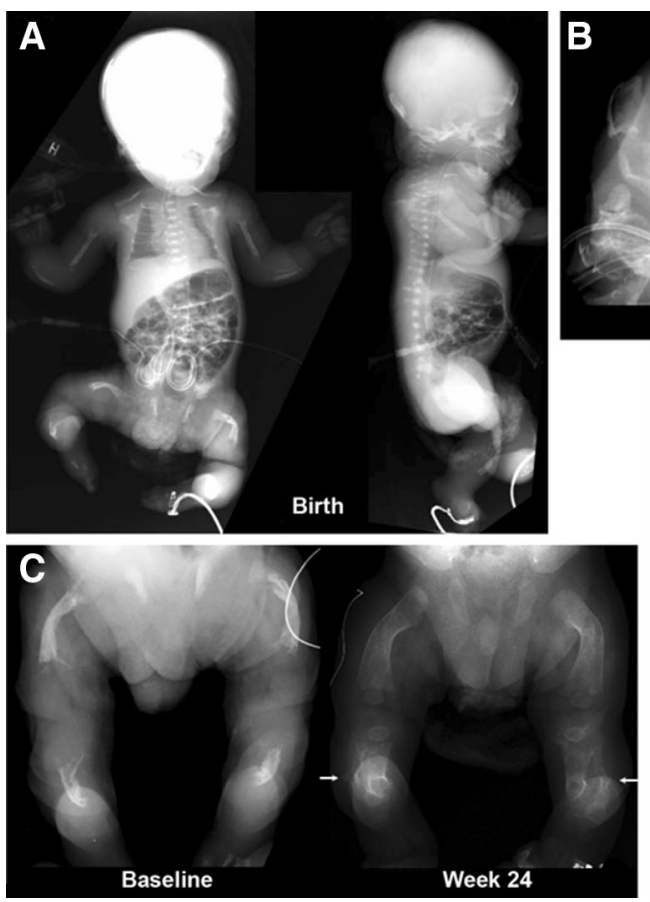

Fig. 9 Efficacy of asfotase alfa in a 20-day-old (at therapy baseline) patient with life-threatening HPP. a This boy had shortened and bowed extremities and "fractures" detected by prenatal sonography at 17-18 weeks gestation. b Before asfotase alfa treatment, little or decreased mineral was present in the frontal, parietal, or occipital bones, skull base, facial bones, and sphenoid. c Before asfotase alfa, the femora were short, sclerotic, bowed, irregular, and lacked defined

alfa, and the risks and benefits of this EzRT in managing HPP in adults require study. These patients may present unique challenges because vascular calcification can be a comorbidity of aging, diabetes mellitus, or chronic kidney disease. Binding of mineral-targeted TNAP to such sites of ectopic calcification could theoretically lead to cardiovascular complications [137]. It is not known if non-targeted ALPs will be useful alternatives. Safe viral vectors for delivery of mineral-targeted or soluble ALPs may streamline HPP treatment in the future.

Funding This study was funded by grant DE12889 from NIDCR, NIH (JLM), Shriners Hospitals for Children (MPW), The Clark and Mildred Cox Inherited Metabolic Bone Disease Fund (MPW), The hypophosphatasia Research Fund (MPW) and the Barnes-Jewish Hospital Foundation (MPW).

\section{Compliance with Ethical Standards}

Conflict of Interest JLM and MPW have received grant support, honoraria, and travel reimbursements from Alexion Pharmaceuticals, Cheshire, CT. JLM has received grant support and honoraria from AM-Pharma, Bunnik, The Netherlands.

Human and Animal Rights and Informed Consent All procedures performed in studies involving human participants were in accordance with the ethical standards of the institutional and/or
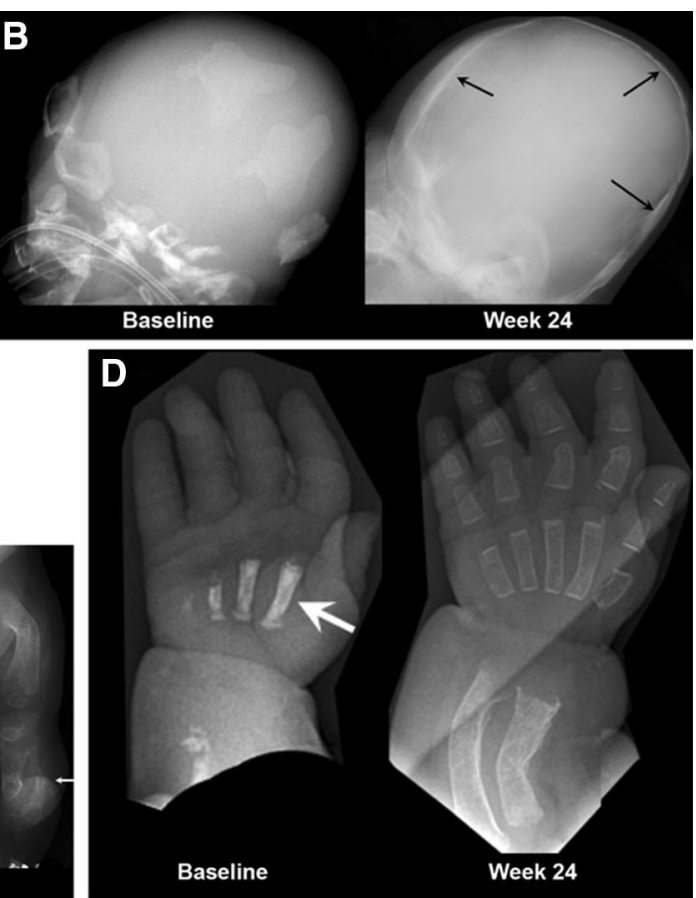

medullary cavities, cortices, and mineralized metaphyses and epiphyses. The fibulae were not calcified. After therapy, striking mineralization was evident. At week 24 of therapy, all areas showed striking remineralization. d The improvement in the left hand and wrist was remarkable. Images taken for the online supplementary data in [9] and reproduced with permission from The New England Journal of Medicine

national research committee and with the 1964 Helsinki declaration and its later amendments or comparable ethical standards. Informed consent was obtained from all individual participants included in the study. All applicable international, national, and/or institutional guidelines for the care and use of animals were followed.

Open Access This article is distributed under the terms of the Creative Commons Attribution 4.0 International License (http://crea tivecommons.org/licenses/by/4.0/), which permits unrestricted use, distribution, and reproduction in any medium, provided you give appropriate credit to the original author(s) and the source, provide a link to the Creative Commons license, and indicate if changes were made.

\section{References}

1. Robison R (1923) The possible significance of hexosephosphoric esters in ossification. Biochem J 17:286

2. Robison R (1932) The significance of phosphoric esters in metabolism. New York University Press, New York

3. Meyer JL (1984) Can biological calcification occur in the presence of pyrophosphate? Arch Biochem Biophys 231:1-8

4. Weiss MJ, Cole DE, Ray K, Whyte MP, Lafferty MA, Mulivor RA, Harris H (1988) A missense mutation in the human liver/ bone/kidney alkaline phosphatase gene causing a lethal form of hypophosphatasia. Proc Natl Acad Sci USA 85:7666-7669

5. Rathbun JC (1948) Hypophosphatasia; a new developmental anomaly. Am J Dis Child 75:822-831 
6. Whyte MP (2013) Hypophosphatasia. In: Thakker RV, Whyte MP, Eisman J, Igarashi T (eds) Genetics of bone biology and skeletal disease. Academic Press, pp 337-360

7. Mornet E, Yvard A, Taillandier A, Fauvert D, Simon-Bouy B (2011) A molecular-based estimation of the prevalence of hypophosphatasia in the European population. Ann Hum Genet 75:439-445

8. Greenberg CR, Taylor CL, Haworth JC, Seargeant LE, Philipps S, Triggs-Raine B, Chodirker BN (1993) A homoallelic Gly317 $\rightarrow$ Asp mutation in ALPL causes the perinatal (lethal) form of hypophosphatasia in Canadian mennonites. Genomics 17:215-217

9. Whyte MP, Greenberg CR, Salman NJ, Bober MB, McAlister WH, Wenkert D, Van Sickle BJ, Simmons JH, Edgar TS, Bauer ML, Hamdan MA, Bishop N, Lutz RE, McGinn M, Craig S, Moore JN, Taylor JW, Cleveland RH, Cranley WR, Lim R, Thacher TD, Mayhew JE, Downs M, Millán JL, Skrinar AM, Crine P, Landy H (2012) Enzyme-replacement therapy in lifethreatening hypophosphatasia. N Engl J Med 366:904-913

10. Millán JL (2006) Mammalian alkaline phosphatases: from biology to applications in medicine and biotechnology. WileyVCH Verlag GmbH \& Co., Weinheim

11. Le Du MH, Stigbrand T, Taussig MJ, Menez A, Stura EA (2001) Crystal structure of alkaline phosphatase from human placenta at 1.8 A resolution. Implication for a substrate specificity. J Biol Chem 276:9158-9165

12. Le Du M-H, Millán JL (2002) Structural evidence of functional divergence in human alkaline phosphatases. J Biol Chem 277:49808-49814

13. Hummer C, Millán JL (1991) Gly429 is the major determinant of uncompetitive inhibition of human germ cell alkaline phosphatase by L-leucine. Biochem J 274(Pt 1):91-95

14. Hoylaerts MF, Manes T, Millán JL (1992) Molecular mechanism of uncompetitive inhibition of human placental and germcell alkaline phosphatase. Biochem J 286(Pt 1):23-30

15. Kozlenkov A, Manes T, Hoylaerts MF, Millan JL (2002) Function assignment to conserved residues in mammalian alkaline phosphatases. J Biol Chem 277:22992-22999

16. Tsonis PA, Argraves WS, Millán JL (1988) A putative functional domain of human placental alkaline phosphatase predicted from sequence comparisons. Biochem J 254:623-624

17. Hoylaerts MF, Ding L, Narisawa S, Van Kerckhoven S, Millán JL (2006) Mammalian alkaline phosphatase catalysis requires active site structure stabilization via the $\mathrm{N}$-terminal amino acid microenvironment. Biochemistry 45:9756-9766

18. Hoylaerts MF, Manes T, Millán JL (1997) Mammalian alkaline phosphatases are allosteric enzymes. J Biol Chem 272:2278122787

19. Fauvert D, Brun-Heath I, Lia-Baldini AS, Bellazi L, Taillandier A, Serre JL, de Mazancourt P, Mornet E (2009) Mild forms of hypophosphatasia mostly result from dominant negative effect of severe alleles or from compound heterozygosity for severe and moderate alleles. BMC Med Genet 10:51

20. Mornet E, Stura E, Lia-Baldini AS, Stigbrand T, Menez A, Le Du MH (2001) Structural evidence for a functional role of human tissue nonspecific alkaline phosphatase in bone mineralization. J Biol Chem 276:31171-31178

21. Hoylaerts MF, Van Kerckhoven S, Kiffer-Moreira T, Sheen C, Narisawa S, Millan JL (2015) Functional significance of calcium binding to tissue-nonspecific alkaline phosphatase. PLoS One 10:e0119874

22. Genge BR, Sauer GR, Wu LN, McLean FM, Wuthier RE (1988) Correlation between loss of alkaline phosphatase activity and accumulation of calcium during matrix vesicle-mediated mineralization. J Biol Chem 263:18513-18519

23. Sharom FJ, Lehto MT (2002) Glycosylphosphatidylinositol-anchored proteins: structure, function, and cleavage by phosphatidylinositol-specific phospholipase C. Biochem Cell Biol 80:535-549

24. Wong YW, Low MG (1994) Biosynthesis of glycosylphosphatidylinositol-anchored human placental alkaline phosphatase: evidence for a phospholipase $\mathrm{C}$-sensitive precursor and its post-attachment conversion into a phospholipase C-resistant form. Biochem J 301(Pt 1):205-209

25. Weiss MJ, Henthorn PS, Lafferty MA, Slaughter C, Raducha M, Harris H (1986) Isolation and characterization of a cDNA encoding a human liver/bone/kidney-type alkaline phosphatase. Proc Natl Acad Sci USA 83:7182-7186

26. Nosjean O, Koyama I, Goseki M, Roux B, Komoda T (1997) Human tissue non-specific alkaline phosphatases: sugar-moietyinduced enzymic and antigenic modulations and genetic aspects. Biochem J 321(Pt 2):297-303

27. Halling Linder C, Narisawa S, Millán JL, Magnusson P (2009) Glycosylation differences contribute to distinct catalytic properties among bone alkaline phosphatase isoforms. Bone 45:987-993

28. Fedde KN, Blair L, Silverstein J, Coburn SP, Ryan LM, Weinstein RS, Waymire K, Narisawa S, Millán JL, MacGregor GR, Whyte MP (1999) Alkaline phosphatase knock-out mice recapitulate the metabolic and skeletal defects of infantile hypophosphatasia. J Bone Miner Res 14:2015-2026

29. Fedde KN, Whyte MP (1990) Alkaline phosphatase (tissuenonspecific isoenzyme) is a phosphoethanolamine and pyridoxal-5'-phosphate ectophosphatase: normal and hypophosphatasia fibroblast study. Am J Hum Genet 47:767-775

30. Ciancaglini P, Yadav MC, Simão AM, Narisawa S, Pizauro JM, Farquharson C, Hoylaerts MF, Millán JL (2010) Kinetic analysis of substrate utilization by native and TNAP-, NPP1-, or PHOSPHO1-deficient matrix vesicles. J Bone Miner Res 25:716-723

31. Pettengill M, Robson S, Tresenriter M, Millan JL, Usheva A, Bingham T, Belderbos M, Bergelson I, Burl S, Kampmann B, Gelinas L, Kollmann T, Bont L, Levy O (2013) Soluble ecto-5' nucleotidase $\left(5^{\prime}-\mathrm{NT}\right)$, alkaline phosphatase, and adenosine deaminase (ADA1) activities in neonatal blood favor elevated extracellular adenosine. J Biol Chem 288:27315-27326

32. Street SE, Kramer NJ, Walsh PL, Taylor-Blake B, Yadav MC, King IF, Vihko P, Wightman RM, Millan JL, Zylka MJ (2013) Tissue-nonspecific alkaline phosphatase acts redundantly with PAP and NT5E to generate adenosine in the dorsal spinal cord. J Neurosci 33:11314-11322

33. Lei W, Nguyen H, Brown N, Ni H, Kiffer-Moreira T, Reese J, Millan JL, Paria BC (2013) Alkaline phosphatases contribute to uterine receptivity, implantation, decidualization, and defense against bacterial endotoxin in hamsters. Reproduction 146:419-432

34. Narisawa S, Yadav MC, Millan JL (2013) In vivo overexpression of tissue-nonspecific alkaline phosphatase increases skeletal mineralization and affects the phosphorylation status of osteopontin. J Bone Miner Res 28:1587-1598

35. Whyte MP (2015) Hypophosphatasia: etiology, nosology, pathogenesis, diagnosis, and treatment. Nat Rev Endocrinol (in press)

36. Whyte MP, Zhang F, Wenkert D, McAlister WH, Mack KE, Benigno MC, Coburn SP, Wagy S, Griffin DM, Ericson KL, Mumm S (2015) Hypophosphatasia: validation and expansion of the clinical nosology for children from 25 years experience with 173 pediatric patients. Bone 75:229-239

37. Wenkert D, McAlister WH, Coburn SP, Zerega JA, Ryan LM, Ericson KL, Hersh JH, Mumm S, Whyte MP (2011) Hypophosphatasia: nonlethal disease despite skeletal presentation in utero (17 new cases and literature review). J Bone Miner Res 26:2389-2398 
38. Baumgartner-Sigl S, Haberlandt E, Mumm S, Scholl-Burgi S, Sergi C, Ryan L, Ericson KL, Whyte MP, Hogler W (2007) Pyridoxine-responsive seizures as the first symptom of infantile hypophosphatasia caused by two novel missense mutations (c.677T $>$ C, p. M226T; c.1112C $>$ T, p.T371I) of the tissuenonspecific alkaline phosphatase gene. Bone 40:1655-1661

39. van den Bos T, Handoko G, Niehof A, Ryan LM, Coburn SP, Whyte MP, Beertsen W (2005) Cementum and dentin in hypophosphatasia. J Dent Res 84:1021-1025

40. Whyte MP, Wenkert D, McAlister WH, Mughal Z, Freemont AJ, Whitehouse R, Baildam E, Mumm S (2009) Chronic recurrent multifocal osteomyelitis mimicked in childhood hypophosphatasia. J Bone Miner Res 24:1493-1505

41. Whyte MP, Teitelbaum SL, Murphy WA, Bergfeld MA, Avioli LV (1979) Adult hypophosphatasia. Clinical, laboratory, and genetic investigation of a large kindred with review of the literature. Medicine (Baltimore) 58:329-347

42. Whyte MP, Murphy WA, Fallon MD (1982) Adult hypophosphatasia with chondrocalcinosis and arthropathy. Variable penetrance of hypophosphatasemia in a large Oklahoma kindred. Am J Med 72:631-641

43. Waymire KG, Mahuren JD, Jaje JM, Guilarte TR, Coburn SP, MacGregor GR (1995) Mice lacking tissue non-specific alkaline phosphatase die from seizures due to defective metabolism of vitamin B-6. Nat Genet 11:45-51

44. Narisawa S, Frohlander N, Millan JL (1997) Inactivation of two mouse alkaline phosphatase genes and establishment of a model of infantile hypophosphatasia. Dev Dyn 208:432-446

45. Whyte MP, Mahuren JD, Vrabel LA, Coburn SP (1985) Markedly increased circulating pyridoxal-5'-phosphate levels in hypophosphatasia. Alkaline phosphatase acts in vitamin B6 metabolism. J Clin Invest 76:752-756

46. Halling Linder C, Englund UH, Narisawa S, Millan JL, Magnusson P (2013) Isozyme profile and tissue-origin of alkaline phosphatases in mouse serum. Bone 53:399-408

47. Beertsen W, VandenBos T, Everts V (1999) Root development in mice lacking functional tissue non-specific alkaline phosphatase gene: inhibition of acellular cementum formation. J Dent Res 78:1221-1229

48. McKee MD, Nakano Y, Masica DL, Gray JJ, Lemire I, Heft R, Whyte MP, Crine P, Millán JL (2011) Enzyme replacement therapy prevents dental defects in a model of hypophosphatasia. J Dent Res 90:470-476

49. Foster BL, Nagatomo KJ, Tso HW, Tran AB, Nociti FH Jr, Narisawa S, Yadav MC, McKee MD, Millan JI, Somerman MJ (2013) Tooth root dentin mineralization defects in a mouse model of hypophosphatasia. J Bone Miner Res 28:271-282

50. Yadav MC, de Oliveira RC, Foster BL, Fong H, Cory E, Narisawa S, Sah RL, Somerman M, Whyte MP, Millan JL (2012) Enzyme replacement prevents enamel defects in hypophosphatasia mice. J Bone Miner Res 27:1722-1734

51. Liu J, Nam HK, Campbell C, Gasque KC, Millan JL, Hatch NE (2014) Tissue-nonspecific alkaline phosphatase deficiency causes abnormal craniofacial bone development in the Alpl(-/-) mouse model of infantile hypophosphatasia. Bone 67:81-94

52. Narisawa S, Wennberg C, Millán JL (2001) Abnormal vitamin B6 metabolism in alkaline phosphatase knock-out mice causes multiple abnormalities, but not the impaired bone mineralization. J. Pathol. 193:125-133

53. Aigner B, Rathkolb B, Klaften M, Sedlmeier R, Klempt M, Wagner S, Michel D, Mayer U, Klopstock T, de Angelis MH, Wolf E (2009) Generation of N-ethyl-N-nitrosourea-induced mouse mutants with deviations in plasma enzyme activities as novel organ-specific disease models. Exp Physiol 94:412-421

54. Sabrautzki S, Rubio-Aliaga I, Hans W, Fuchs H, Rathkolb B, Calzada-Wack J, Cohrs CM, Klaften M, Seedorf H, Eck S,
Benet-Pages A, Favor J, Esposito I, Strom TM, Wolf E, LorenzDepiereux B, Hrabe de Angelis M (2012) New mouse models for metabolic bone diseases generated by genome-wide ENU mutagenesis. Mamm Genome 23:416-430

55. Hough TA, Polewski M, Johnson K, Cheeseman M, Nolan PM, Vizor L, Rastan S, Boyde A, Pritzker K, Hunter AJ, Fisher EMC, Terkeltaub R, Brown SDM (2007) Novel mouse model of autosomal semidominant adult hypophosphatasia has a splice site mutation in the tissue nonspecific alkaline phosphatase gene Akp2. J Bone Miner Res 22:1397-1407

56. Foster BL, Sheen CR, Hatch NE, Liu J, Cory E, Narisawa S, Kiffer-Moreira T, Sah RL, Whyte MP, Somerman MJ, Millan JL (2015) Periodontal defects in the A116T knock-in murine model of odontohypophosphatasia. J Dent Res 94:706-714

57. Ali SY, Sajdera SW, Anderson HC (1970) Isolation and characterization of calcifying matrix vesicles from epiphyseal cartilage. Proc Natl Acad Sci USA 67:1513-1520

58. Bernard GW (1978) Ultrastructural localization of alkaline phosphatase in initial intramembranous osteogenesis. Clin Orthop Relat Res 135:218-225

59. Morris DC, Masuhara K, Takaoka K, Ono K, Anderson HC (1992) Immunolocalization of alkaline phosphatase in osteoblasts and matrix vesicles of human fetal bone. Bone Miner 19:287-298

60. Anderson HC, Harmey D, Camacho NP, Garimella R, Sipe JB, Tague S, Bi X, Johnson K, Terkeltaub R, Millan JL (2005) Sustained osteomalacia of long bones despite major improvement in other hypophosphatasia-related mineral deficits in tissue nonspecific alkaline phosphatase/nucleotide pyrophosphatase phosphodiesterase 1 double-deficient mice. Am J Pathol 166:1711-1720

61. Anderson HC, Hsu HH, Morris DC, Fedde KN, Whyte MP (1997) Matrix vesicles in osteomalacic hypophosphatasia bone contain apatite-like mineral crystals. Am J Pathol 151:1555-1561

62. Anderson HC, Sipe JB, Hessle L, Dhanyamraju R, Atti E, Camacho NP, Millan JL (2004) Impaired calcification around matrix vesicles of growth plate and bone in alkaline phosphatase-deficient mice. Am J Pathol 164:841-847

63. Russell RG (1965) Excretion of inorganic pyrophosphate in hypophosphatasia. Lancet 2:461-464

64. Russell RG, Bisaz S, Donath A, Morgan DB, Fleisch H (1971) Inorganic pyrophosphate in plasma in normal persons and in patients with hypophosphatasia, osteogenesis imperfecta, and other disorders of bone. J Clin Invest 50:961-969

65. Fleisch H, Russell RG, Straumann F (1966) Effect of pyrophosphate on hydroxyapatite and its implications in calcium homeostasis. Nature 212:901-903

66. Harmey D, Hessle L, Narisawa S, Johnson KA, Terkeltaub R, Millán JL (2004) Concerted regulation of inorganic pyrophosphate and osteopontin by Akp2, Enppl, and Ank: an integrated model of the pathogenesis of mineralization disorders. Am J Pathol 164:1199-1209

67. Hessle L, Johnson KA, Anderson HC, Narisawa S, Sali A, Goding JW, Terkeltaub R, Millan JL (2002) Tissue-nonspecific alkaline phosphatase and plasma cell membrane glycoprotein-1 are central antagonistic regulators of bone mineralization. Proc Natl Acad Sci USA 99:9445-9449

68. Johnson KA, Hessle L, Vaingankar S, Wennberg C, Mauro S, Narisawa S, Goding JW, Sano K, Millan JL, Terkeltaub R (2000) Osteoblast tissue-nonspecific alkaline phosphatase antagonizes and regulates PC-1. Am J Physiol Regul Integr Comp Physiol 279:R1365-R1377

69. Simao AM, Yadav MC, Narisawa S, Bolean M, Pizauro JM, Hoylaerts MF, Ciancaglini P, Millan JL (2010) Proteoliposomes harboring alkaline phosphatase and nucleotide pyrophosphatase as matrix vesicle biomimetics. J Biol Chem 285:7598-7609 
70. Yadav MC, Simão AM, Narisawa S, Huesa C, McKee MD, Farquharson C, Millán JL (2011) Loss of skeletal mineralization by the simultaneous ablation of PHOSPHO1 and alkaline phosphatase function: a unified model of the mechanisms of initiation of skeletal calcification. J Bone Miner Res 26:286-297

71. Millan JL (2013) The role of phosphatases in the initiation of skeletal mineralization. Calcif Tissue Int 93:299-306

72. Moss DW, Eaton RH, Smith JK, Whitby LG (1967) Association of inorganic-pyrophosphatase activity with human alkalinephosphatase preparations. Biochem J 102:53-57

73. Majeska RJ, Wuthier RE (1975) Studies on matrix vesicles isolated from chick epiphyseal cartilage. Association of pyrophosphatase and ATPase activities with alkaline phosphatase. Biochim Biophys Acta 391:51-60

74. Fallon MD, Whyte MP, Teitelbaum SL (1980) Stereospecific inhibition of alkaline phosphatase by L-tetramisole prevents in vitro cartilage calcification. Lab Invest 43:489-494

75. Rezende AA, Pizauro JM, Ciancaglini P, Leone FA (1994) Phosphodiesterase activity is a novel property of alkaline phosphatase from osseous plate. Biochem J 301(Pt 2):517-522

76. Coburn SP, Slominski A, Mahuren JD, Wortsman J, Hessle L, Millán JL (2003) Cutaneous metabolism of vitamin B-6. J Invest Dermatol 120:292-300

77. Jansonius JN (1998) Structure, evolution and action of vitamin B6-dependent enzymes. Curr Opin Struct Biol 8:759-769

78. Whyte MP, Landt M, Ryan LM, Mulivor RA, Henthorn PS, Fedde KN, Mahuren JD, Coburn SP (1995) Alkaline phosphatase: placental and tissue-nonspecific isoenzymes hydrolyze phosphoethanolamine, inorganic pyrophosphate, and pyridoxal $5^{\prime}$-phosphate. Substrate accumulation in carriers of hypophosphatasia corrects during pregnancy. J Clin Invest 95:1440-1445

79. Chodirker BN, Coburn SP, Seargeant LE, Whyte MP, Greenberg CR (1990) Increased plasma pyridoxal-5'-phosphate levels before and after pyridoxine loading in carriers of perinatal/infantile hypophosphatasia. J Inherit Metab Dis 13:891-896

80. Whyte MP, Mahuren JD, Fedde KN, Cole FS, McCabe ER, Coburn SP (1988) Perinatal hypophosphatasia: tissue levels of vitamin B6 are unremarkable despite markedly increased circulating concentrations of pyridoxal-5'-phosphate. Evidence for an ectoenzyme role for tissue-nonspecific alkaline phosphatase. J Clin Invest 81:1234-1239

81. Narisawa S, Hasegawa H, Watanabe K, Millán JL (1994) Stagespecific expression of alkaline phosphatase during neural development in the mouse. Dev Dyn 201:227-235

82. Fonta C, Negyessy L (2015) Subcellular biochemistry. In: Fonta C, Negyessy L (eds) Neuronal tissue-nonspecific alkaline phosphatase (TNAP). Springer, Dordrecht

83. Hanics J, Barna J, Xiao J, Millan JL, Fonta C, Negyessy L (2012) Ablation of TNAP function compromises myelination and synaptogenesis in the mouse brain. Cell Tissue Res 349:459-471

84. Fleshood HL, Pitot HC (1969) O-phosphorylethanolamine ammonia lyase, a new pyridoxal phosphate-dependent enzyme. Biochem Biophys Res Commun 36:110-118

85. Fleshood HL, Pitot HC (1970) The metabolism of O-phosphorylethanolamine in animal tissues. I. O-phosphorylethanolamine phospho-lyase: partial purification and characterization. J Biol Chem 245:4414-4420

86. Fleshood HL, Pitot HC (1970) The metabolism of O-phosphorylethanolamine in animal tissues. II. Metabolic regulation of O-phosphorylethanolamine phospho-lyase in vivo. Arch Biochem Biophys 141:423-429

87. Millán JL, Whyte MP, Avioli LV, Fishman WH (1980) Hypophosphatasia (adult form): quantitation of serum alkaline phosphatase isoenzyme activity in a large kindred. Clin Chem $26: 840-845$
88. Wennberg C, Hessle L, Lundberg P, Mauro S, Narisawa S, Lerner UH, Millán JL (2000) Functional characterization of osteoblasts and osteoclasts from alkaline phosphatase knockout mice. J Bone Miner Res 15:1879-1888

89. Johnson K, Goding J, Van Etten D, Sali A, Hu SI, Farley D, Krug H, Hessle L, Millán JL, Terkeltaub R (2003) Linked deficiencies in extracellular PP(i) and osteopontin mediate pathologic calcification associated with defective PC-1 and ANK expression. J Bone Miner Res 18:994-1004

90. Harmey D, Johnson KA, Zelken J, Camacho NP, Hoylaerts MF, Noda M, Terkeltaub R, Millán JL (2006) Elevated skeletal osteopontin levels contribute to the hypophosphatasia phenotype in Akp2(-/-) mice. J Bone Miner Res 21:1377-1386

91. Goldberg HA, Warner KJ, Li MC, Hunter GK (2001) Binding of bone sialoprotein, osteopontin and synthetic polypeptides to hydroxyapatite. Connect Tissue Res 42:25-37

92. Christensen B, Nielsen MS, Haselmann KF, Petersen TE, Sorensen ES (2005) Post-translationally modified residues of native human osteopontin are located in clusters: identification of 36 phosphorylation and five O-glycosylation sites and their biological implications. Biochem J 390:285-292

93. Hunter GK, Kyle CL, Goldberg HA (1994) Modulation of crystal formation by bone phosphoproteins: structural specificity of the osteopontin-mediated inhibition of hydroxyapatite formation. Biochem J 300(Pt 3):723-728

94. Jono S, Peinado C, Giachelli CM (2000) Phosphorylation of osteopontin is required for inhibition of vascular smooth muscle cell calcification. J Biol Chem 275:20197-20203

95. Pampena DA, Robertson KA, Litvinova O, Lajoie G, Goldberg HA, Hunter GK (2004) Inhibition of hydroxyapatite formation by osteopontin phosphopeptides. Biochem J 378:1083-1087

96. Addison WN, Masica DL, Gray JJ, McKee MD (2010) Phosphorylation-dependent inhibition of mineralization by osteopontin ASARM peptides is regulated by PHEX cleavage. J Bone Miner Res 25:695-705

97. Yadav MC, Huesa C, Narisawa S, Hoylaerts MF, Moreau A, Farquharson C, Millan JL (2014) Ablation of osteopontin improves the skeletal phenotype of phospho1(-/-) mice. J Bone Miner Res 29:2369-2381

98. Goldberg RF, Austen WG Jr, Zhang X, Munene G, Mostafa G, Biswas S, McCormack M, Eberlin KR, Nguyen JT, Tatlidede HS, Warren HS, Narisawa S, Millán JL, Hodin RA (2008) Intestinal alkaline phosphatase is a gut mucosal defense factor maintained by enteral nutrition. Proc Natl Acad Sci USA 105:3551-3556

99. Malo MS, Alam SN, Mostafa G, Zeller SJ, Johnson PV, Mohammad N, Chen KT, Moss AK, Ramasamy S, Faruqui A, Hodin S, Malo PS, Ebrahimi F, Biswas B, Narisawa S, Millan JL, Warren HS, Kaplan JB, Kitts CL, Hohmann EL, Hodin RA (2010) Intestinal alkaline phosphatase preserves the normal homeostasis of gut microbiota. Gut 59:1476-1484

100. Malo MS, Moaven O, Muhammad N, Biswas B, Alam SN, Economopoulos KP, Gul SS, Hamarneh SR, Malo NS, Teshager A, Mohamed MM, Tao Q, Narisawa S, Millan JL, Hohmann EL, Warren HS, Robson SC, Hodin RA (2014) Intestinal alkaline phosphatase promotes gut bacterial growth by reducing the concentration of luminal nucleotide triphosphates. Am J Physiol Gastrointest Liver Physiol 306:G826-G838

101. Panchal J, Uttchin V (2003) Management of craniosynostosis. Plast Reconstr Surg 111:2032-2048 quiz 2049

102. Liu J, Campbell C, Nam HK, Caron A, Yadav MC, Millan JL, Hatch NE (2015) Enzyme replacement for craniofacial skeletal defects and craniosynostosis in murine hypophosphatasia. Bone 78:203-211

103. Gasque KC, Foster BL, Kuss P, Yadav MC, Liu J, KifferMoreira T, van Elsas A, Hatch N, Somerman MJ, Millan JL 
(2015) Improvement of the skeletal and dental hypophosphatasia phenotype in Alpl(-/-) mice by administration of soluble (nontargeted) chimeric alkaline phosphatase. Bone 72:137-147

104. Weber B, Schwabegger AH, Oberaigner W, Rumer-Moser A, Steiner H (2010) Incidence of perinatal complications in children with premature craniosynostosis. J Perinat Med 38:319-325

105. Baumann JM, Bisaz S, Felix R, Fleisch H, Ganz U, Russell RG (1977) The role of inhibitors and other factors in the pathogenesis of recurrent calcium-containing renal stones. Clin Sci Mol Med 53:141-148

106. Laminski NA, Meyers AM, Sonnekus MI, Smyth AE (1990) Prevalence of hypocitraturia and hypopyrophosphaturia in recurrent calcium stone formers: as isolated defects or associated with other metabolic abnormalities. Nephron 56:379-386

107. Russell RG, Smith R, Preston C, Walton RJ, Woods CG, Henderson RG, Norman AW (1975) The effect of 1,25-dihydroxycholecalciferol on renal tubular reabsorption of phosphate, intestinal absorption of calcium and bone histology in hypophosphataemic renal tubular rickets. Clin Sci Mol Med 48:177-186

108. Rodriguez E, Bober MB, Davey L, Zamora A, Li Puma AB, Chidekel A, Shaffer TH (2012) Respiratory mechanics in an infant with perinatal lethal hypophosphatasia treated with human recombinant enzyme replacement therapy. Pediatr Pulmonol 47:917-922

109. Coe JD, Murphy WA, Whyte MP (1986) Management of femoral fractures and pseudofractures in adult hypophosphatasia. J Bone Joint Surg Am 68:981-990

110. Whyte MP, Valdes R Jr, Ryan LM, McAlister WH (1982) Infantile hypophosphatasia: enzyme replacement therapy by intravenous infusion of alkaline phosphatase-rich plasma from patients with Paget's bone disease. J Pediatr 101:379-386

111. Whyte MP, McAlister WH, Patton LS, Magill HL, Fallon MD, Lorentz WB Jr, Herrod HG (1984) Enzyme replacement therapy for infantile hypophosphatasia attempted by intravenous infusions of alkaline phosphatase-rich Paget plasma: results in three additional patients. J Pediatr 105:926-933

112. Weninger M, Stinson RA, Plenk H Jr, Bock P, Pollak A (1989) Biochemical and morphological effects of human hepatic alkaline phosphatase in a neonate with hypophosphatasia. Acta Paediatr Scand Suppl 360:154-160

113. Whyte MP, Habib D, Coburn SP, Tecklenburg F, Ryan L, Fedde KN, Stinson RA (1992) Failure of hyperphosphatasemia by intravenous infusion of purified placental alkaline phosphatase (ALP) to correct severe hypophosphatasia: evidence against a role for circulating ALP in skeletal mineralization (abstract). J Bone Miner Res 7:S155

114. Whyte MP, Kurtzberg J, McAlister WH, Mumm S, Podgornik MN, Coburn SP, Ryan LM, Miller CR, Gottesman GS, Smith AK, Douville J, Waters-Pick B, Armstrong RD, Martin PL (2003) Marrow cell transplantation for infantile hypophosphatasia. J Bone Miner Res 18:624-636

115. Cahill RA, Wenkert D, Perlman SA, Steele A, Coburn SP, McAlister WH, Mumm S, Whyte MP (2007) Infantile hypophosphatasia: transplantation therapy trial using bone fragments and cultured osteoblasts. J Clin Endocrinol Metab 92:2923-2930

116. Whyte MP, Mumm S, Deal C (2007) Adult hypophosphatasia treated with teriparatide. J Clin Endocrinol Metab 92:1203-1208

117. Camacho PM, Painter S, Kadanoff R (2008) Treatment of adult hypophosphatasia with teriparatide. Endocr Pract 14:204-208

118. Doshi KB, Hamrahian AH, Licata AA (2009) Teriparatide treatment in adult hypophosphatasia in a patient exposed to bisphosphonate: a case report. Clin Cases Miner Bone Metab 6:266-269
119. Schalin-Jantti C, Mornet E, Lamminen A, Valimaki MJ (2010) Parathyroid hormone treatment improves pain and fracture healing in adult hypophosphatasia. J Clin Endocrinol Metab 95:5174-5179

120. Gagnon C, Sims NA, Mumm S, McAuley SA, Jung C, Poulton IJ, Ng KW, Ebeling PR (2010) Lack of sustained response to teriparatide in a patient with adult hypophosphatasia. J Clin Endocrinol Metab 95:1007-1012

121. Laroche M (2012) Failure of teriparatide in treatment of bone complications of adult hypophosphatasia. Calcif Tissue Int 90:250

122. Vahle JL, Long GG, Sandusky G, Westmore M, Ma YL, Sato M (2004) Bone neoplasms in F344 rats given teriparatide [rhPTH(1-34)] are dependent on duration of treatment and dose. Toxicol Pathol 32:426-438

123. McColm J, Hu L, Womack T, Tang CC, Chiang AY (2014) Single- and multiple-dose randomized studies of blosozumab, a monoclonal antibody against sclerostin, in healthy postmenopausal women. J Bone Miner Res 29:935-943

124. Kasugai S, Fujisawa R, Waki Y, Miyamoto K, Ohya K (2000) Selective drug delivery system to bone: small peptide (Asp)6 conjugation. J Bone Miner Res 15:936-943

125. Yokogawa K, Miya K, Sekido T, Higashi Y, Nomura M, Fujisawa R, Morito K, Masamune Y, Waki Y, Kasugai S, Miyamoto K (2001) Selective delivery of estradiol to bone by aspartic acid oligopeptide and its effects on ovariectomized mice. Endocrinology 142:1228-1233

126. Nishioka T, Tomatsu S, Gutierrez MA, Miyamoto K, Trandafirescu GG, Lopez PL, Grubb JH, Kanai R, Kobayashi H, Yamaguchi S, Gottesman GS, Cahill R, Noguchi A, Sly WS (2006) Enhancement of drug delivery to bone: characterization of human tissue-nonspecific alkaline phosphatase tagged with an acidic oligopeptide. Mol Genet Metab 88:244-255

127. Millan JL, Narisawa S, Lemire I, Loisel TP, Boileau G, Leonard P, Gramatikova S, Terkeltaub R, Camacho NP, McKee MD, Crine P, Whyte MP (2008) Enzyme replacement therapy for murine hypophosphatasia. J Bone Miner Res 23:777-787

128. Yadav MC, Lemire I, Leonard P, Boileau G, Blond L, Beliveau M, Cory E, Sah RL, Whyte MP, Crine P, Millan JL (2011) Dose response of bone-targeted enzyme replacement for murine hypophosphatasia. Bone 49:250-256

129. Nociti FH Jr, Berry JE, Foster BL, Gurley KA, Kingsley DM, Takata T, Miyauchi M, Somerman MJ (2002) Cementum: a phosphate-sensitive tissue. J Dent Res 81:817-821

130. Foster BL, Nagatomo KJ, Nociti FH Jr, Fong H, Dunn D, Tran AB, Wang W, Narisawa S, Millan JL, Somerman MJ (2012) Central role of pyrophosphate in acellular cementum formation. PLoS ONE 7:e38393

131. Whyte MP, Rockman-Greenberg C, Ozono K, Riese R, Moseley S, Melian A, Thompson D, Bishop N, Hofmann C, study ENB002-08, ENB-003-08, ENB-010-10ENB-011-10 Investigators (2015) Asfotase alfa treatment improves survival for perinatal and infantile hypophosphatasia. J Clin Endocrinol Metab. doi:10.1210/jc.2015-3462

132. Whyte MP, Madson KL, Phillips KL, Reeves A, McAlister WH, Yakimoski A, Mack KE, Hamilton K, Kagan K, Fugita K, Thompson D, Moseley S, Odrljin T, Greenberg CR Asfotase alfa therapy for children with hypophosphatasia (submitted)

133. Kiffer-Moreira T, Sheen CR, Gasque K, Bolean M, Ciancaglini P, Van Elsas A, Hoylaerts MF, Millán JL (2014) Catalytic signature of a heat-stable, chimeric human alkaline phosphatase with therapeutic potential. PLoS One 9(2):e89374

134. Yamamoto $\mathrm{S}$, Orimo $\mathrm{H}$, Matsumoto $\mathrm{T}$, Iijima $\mathrm{O}$, Narisawa $\mathrm{S}$, Maeda T, Millán JL, Shimada T (2011) Prolonged survival and 
phenotypic correction of Akp2(-/-) hypophosphatasia mice by lentiviral gene therapy. J Bone Miner Res 26:135-142

135. Matsumoto T, Miyake K, Yamamoto S, Orimo H, Miyake N, Odagaki Y, Adachi K, Iijima O, Narisawa S, Millán JL, Fukunaga Y, Shimada T (2011) Rescue of severe infantile hypophosphatasia mice by AAV-mediated sustained expression of soluble alkaline phosphatase. Hum Gene Ther 22:1355-1364

136. Sugano H, Matsumoto $\mathrm{T}$, Miyake $\mathrm{K}$, Watanabe A, Iijima $\mathrm{O}$, Migita M, Narisawa S, Millan JL, Fukunaga Y, Shimada T
(2012) Successful gene therapy in utero for lethal murine hypophosphatasia. Hum Gene Ther 23:399-406

137. Sheen CR, Kuss P, Narisawa S, Yadav MC, Nigro J, Wang W, Chlea TN, Sergienko E, Kapoor K, Jackson MR, Hoylaerts MF, Pinkerton AB, O’Neill WC, Millán JL (2015) Pathophysiological role of vascular smooth muscle alkaline phosphatase in medial artery calcification. J Bone Miner Res 30:824-836. doi:10.1002/jbmr.2420 